\title{
Klimato kaitos aspektai lietuviškame internete: ką galima sužinoti iš bendros statistinès informacijos
}

\author{
Justas Kažys \\ Vilniaus universitetas, \\ M. K. Čiurlionio g. 21, \\ LT-03101 Vilnius \\ El.paštas justas.kazys@gf.vu.lt
}

\begin{abstract}
Kažys J. Klimato kaitos aspektai lietuviškame internete: ką galima sužinoti iš bendros statistinès informacijos. Geologija. Geografija. 2017. T. 3(1). ISSN 23517549 .

Klimato kaita yra viena plačiausiai aptarinejjamų temų pasaulyje. Šio darbo tikslas - remiantis kiekybinès ir kokybinès informacijos analize įvertinti, kaip klimato kaitos aspektai atsispindi lietuviškuose interneto puslapiuose. Nuo $2015 \mathrm{~m}$. vasario $4 \mathrm{~d}$. iki $2016 \mathrm{~m}$. rugsèjo $20 \mathrm{~d}$. atliktame tyrime analizuoti interneto paieškos sistemų Google, Bing ir Yahoo užklausą „klimato kaita “ atitinkantys populiariausiųjų dešimtukų rezultatai. Taip pat dèmesys skirtas Aplinkos ministerijos, Aplinkos apsaugos agentūros, Lietuvos hidrometeorologijos tarnybos, Aplinkosaugos koalicijos ir Europos aplinkos agentūros puslapiuose esančios bendrosios ir naujienų pavidalu pateikiamos informacijos apie klimato kaitą analizei. Išsami statistinių rezultatų analizė atskleidè, kad dažniausiai lankomas ir matomas informacijos šaltinis yra lietuviškoje Vikipedijoje esantis straipsnis. Vykdant tyrimą nustatytos egzistuojančios spragos ir galimi sprendimo variantai siekiant pagerinti visuomenès informuotumą klimato kaitos srityje.
\end{abstract}

Raktažodžiai: klimato kaita, aplinkosauga, interneto paieškos sistemos, Europos aplinkos agentūra, žiniasklaida, nevyriausybinès organizacijos

\section{IVADAS}

Klimato kaitos (KK) diskursas Lietuvoje, kaip ir daugelyje Europos Sąjungos šalių, yra itin aktualus. Nors socialinių ir ekonominių krizių šešèlyje klimato kaita nèra opiausia problema, remiantis naujausiais Eurobarometero (2014a) duomenimis, Lietuvoje jos svarba neabejoja $88 \%$ gyventojų, ir šis skaičius vis auga. Taip pat net $59 \%$ Lietuvos gyventoju mano, kad ateityje mokslo ir technologinių inovacijų poveikis kovai su KK bus teigiamas (Eurobarometer, 2014b). Vienas iš prieinamiausių būdų gauti informacijos apie KK yra internetas (Anderson, 2009) - juo Lietuvoje naudojasi daugiau nei $76 \%$ gyventojų (IVPK, 2016). Tačiau didžioji dalis informacijos apie klimato kaitą internete pateikiama ne lietuvių, o kitomis (daugiausia anglų) kalbomis. Tik $38 \%$ lietuvių pakankami gerai moka anglų kalbą, kad galètų laisvai naudotis informacija šia kalba (Eurobarometer, 2012), o susidaręs informacinis vakuumas yra viena iš galimų priežasčių, kodèl Lietuvos gyventojai mažai aktyvūs imantis veiksmu klimato kaitos srityje (Eurobarometer, 2014a).

Paskutinèje (2014 m. paskelbtoje) Tarpvyriausybinès klimato kaitos komisijos (IPCC) ataskaitoje pabréžiama, kad vis daugiau demesio skiriama prisitaikymo galimybių paieškai ir visuomenès jautrumo vertinimui naudojant ịvairius informavimo bei visuomenès (asmeninès) savimonès skatinimo instrumentus (IPCC, 2014). Analogiškus tikslus deklaruoja ir Europos Sąunga (ES), ịvardydama kovą su KK kaip vieną svarbiausią savo prioritetą (Europos komisija, 2013, 2014). Lietuva, būdama ES dalimi, prisiima ir vykdo visus ES isipareigojimus bei dalyvauja formuojant KK politiką (Aplinkos ministerija, 2013). Lietuvos Respublika kovą su KK yra paskelbusi nacionaliniu 
prioritetu, sukūrusi nacionalinę klimato kaitos strategiją (LR Seimas, 2012) ir jos tikslų igyvendinimo planą (LR Vyriausybè, 2013).

Deja, tyrimų, rodančių KK problematikos suvokimo lygmeni Lietuvos visuomenèje, nèra itin daug. Daugiausia tyrimų šioje srityje atlikta vykdant „RINOVA: rizikos suvokimas, viešoji komunikacija ir inovatyvus valdymas žinių visuomenejje" projektą (Rinkevičius, 2009). Dėmesys sutelktas $\mathfrak{i}$ tyrimo teorines ir metodologines prielaidas (Juraité, Telešienè, 2009) bei KK diskursui tradicinèse žiniasklaidos priemonėse (Balžekienè ir kt., 2008; 2009; Telešienè, 2009) aptarti, kai internetinès žiniasklaidos priemonès ił tyrimą itrauktos tik pastaruoju metu (Jančevskaite, Telešienè, 2013). G. Valiuškevičius (2015) nagrinejjo klimato kaitos diskursą baigiamuosiuose studentų darbuose, o J. Kažys (2016), remdamasis interneto paieškos sistemų rezultatais, atliko frazès „klimato kaita“ Baltijos jūros regiono kalbomis analizę. Svarbu pabrěžti, kad A. Telešienè su kolegomis iš Kauno technologijos universiteto prisidèjo rengiant požiūrio it aplinkosaugines problemas, taip pat ir KK, Europos kontekste studiją (Green European..., 2017).

Vien tik sąmoningumo stiprinimo ir diskusijų, susijusių su klimato kaita, nebūtinai pakanka norint paveikti žmogaus elgseną ar politinių veiksmų raidą. Kiti veiksniai, ypač galimos strategijos pasirinkimas, atsirandančios progos ar esantys trikdžiai tampa itin svarbūs (Moser, Dilling, 2012). Vienas iš būdų skleisti informaciją - padaryti ją daugiakalbę. Vikipedijos (wikipedia. org) ir Europos aplinkos agentūros (eea.europa. eu) puslapiai yra geriausi daugiakalbių, patikimą informaciją apie KK pateikiančių, interneto svetainių pavyzdžiai. „Gerąja praktika“ galima laikyti BalticClimate toolkit (toolkit.balticclimate.org), kuris pateikia informaciją 11 Baltijos jūros regiono kalbų. Puslapyje galima rasti klausimų apie KK apžvalgas bei specializuotų patarimų sprendimu priemėjams, planuotojams ir verslo sektoriui (Stockholm Environment Institute, 2012).

Ivairiuose tyrimuose itin akcentuojamas gebejimas bendradarbiauti ir tinkamai pateikti informaciją apie KK (Greer, Mensing, 2006; Center for Research..., 2009; CCCAG, 2010; Leviston ir kt., 2014; van der Linden ir kt., 2014). Bendradarbiavimas tarp mokslininkų, nevyriausybinių organizacijų (NVO) atstovų, vietos gyventojų ir
KK problemos suvokimas tarp įvairiu visuomenès grupių Lietuvoje nagrinètas vykdant Baltijos jūros regiono projektus (Bray, 2010; Vidickienè ir kt., 2010; Wiréhn, 2011; Piwowarczyk ir kt., 2012; Kažys ir kt., 2013). Taip pat tyrimuose akcentuojamas aktyvus NVO vaidmuo: A. Jamison ir L. Rinkevičius (2010) aptaria socialinių judejjimų poveiki klimato kaitos diskurso ir žinojimo raidai, o G. Jonušauskaitè (2014), I. Ringailaitė (2014), J. Kažys ir kt. (2016) pateikia konkrečių taikymo pavyzdžių.

Pagrindinis šio tyrimo tikslas - remiantis interneto paieškos sistemų ir aplinkosauginių organizacijų interneto portalų duomenimis, ištirti ir iqvertinti esamos lietuviškai internete pateikiamos informacijos apie klimato kaitą kiekybinius ir kokybinius rodiklius. Pateikiama daugialype rezultatų interpretacija netiesiogiai implikuoja $\mathfrak{i}$ piliečių informuotumo lygio spragas lietuviškame internete, kartu palikdama erdvès diskusijai. Gauti rezultatai leis tinkamai įvertinti pagrindinius KK problematikos sklaidos principus lietuviškoje interneto erdvèje, suteiks galimybę imtis konkrečių veiksmų kiekybiškai ir kokybiškai gerinant KK informaciją. Tyrimas leidžia išsamiau pažvelgti $\mathfrak{i}$ interneto tinklalapiuose (ypač vyriausybinių ir nevyriausybinių organizacijų) pateikiamos informacijos struktūrą, nustatyti galimus informacijos optimizavimo ir aktualizavimo žingsnius ateityje.

\section{PRADINIAI DUOMENYS IR METODIKA}

Tyrimams panaudoti statistiniai frazès „klimato kaita" užklausos interneto paieškos sistemose duomenys. Frazė i paieškos sistemas buvo ịvedama tik vardininko linksniu nenaudojant kabučių. Tikètina, kad eilinis interneto vartotojas, ieškodamas informacijos apie KK, suves šią frazę paieškos sistemose Google, Bing arba Yahoo, nes Lietuvoje jos populiariausios - $2016 \mathrm{~m}$. antro ketvirčio duomenimis, atitinkamai 96,33; 1,72 ir $0,99 \%$ (StatCounter, 2016). Ketvirtoji pagal populiarumą interneto paieškos sistema Yandex nebuvo analizuota, kadangi nemaža dalis užklausos rezultatų yra pateikiama rusų kalba. Siekiant išvengti šališkumo dèl galimo to paties vartotojo ir frazès susiejimo interneto paieškos sistemose, kiekvienai užklausai naudotas kitas interneto prisijungimo IP adresas, o puslapių 
lankymosi istorija buvo išvalyta. Reikia pažymèti, kad interneto paieškos sistemose nuorodos vieta nuolatos keičiasi, tačiau nuorodos poslinkiai per dieną ar savaitę nèra reikšmingi, t. y. interneto šaltinio pozicija daugiausia pasislenka per \pm 2 vietas. Siekiant iliustruoti frazès paieškos rezultatų kitimo tendencijas pasirinktas 4-5 ménesių intervalas, o pusantrų metų laikotarpis leidžia apibendrinti vidutines paieškos rezultatų reikšmes. Frazès paieška vykdyta nuo 2015 m. vasario 4 d. iki 2016 m. rugsèjo 20 d., iš viso 6 kartus (1 lentelè). 1 lentelèje pateikiamas bendras rezultatų, atitinkančių frazę „klimato kaita“, skaičius. Paieškos sistemoje Google užklausą atitinkančių rezultatų skaičius daugiau nei dešimt kartų viršija kitų sistemų rezultatus. Kadangi pirmojo paieškos puslapio rezultatams tenka 91,5 \% visų peržiūrų, o pirmosioms trims pozicijoms per $60 \%$ (Chitika, 2013), tyrime remtasi tik populiariausiųjų dešimtuko ir trejetuko užklausą atitinkančiais rezultatais.

1 lentelè. Rezultatų, atitinkančių užklausą „klimato kaita", skaičius interneto paieškos sistemose

Table 1. The number of results corresponding to request 'climate change' on internet search engines

\begin{tabular}{cccc}
\hline $\begin{array}{c}\text { Užklausos data } \\
\text { Request date }\end{array}$ & Google & Bing & Yahoo \\
\hline 20150204 & 222000 & - & - \\
\hline 20150604 & 223000 & - & - \\
\hline 20151027 & 248000 & 17200 & 17200 \\
\hline 20160114 & 295000 & 19000 & 19200 \\
\hline 20160517 & 286000 & 17700 & 17800 \\
\hline 20160920 & 204000 & 17600 & 17200 \\
\hline
\end{tabular}

Ivertinta bent kartą i t populiariausiųjų dešimtuko pozicijas patekusių frazès "klimato kaita“ paieškos sistemoje Google užklausą atitinkančių interneto šaltinių dinamika (kaip pasikeitè puslapio reitingas skirtingų užklausų metu) bei pasikartojimo dažnis (kiek kartų šaltinis pateko ił populiariausiųjų dešimtuką ir trejetuką). Toliau analizuojant stengtasi atsakyti $\mathfrak{i}$ klausimus, susijusius su paieškos rezultatų struktūra (2 lentelè): kas, kur, kada, kodèl, kaip ir kiek?

Populiariausiųjų trejetuko rezultatai suskirstyti atsižvelgiant i 2 lenteleje pateiktas informacijos autorių (klausimas kas?) kategorijas. Visuomeninių puslapių kategorija buvo išskaidyta $\mathfrak{i}$
Vikipedija ir kitus. Valstybinių ir NVO puslapių autoryste buvo išskaidyta i vietinị (lietuvišką) ir regioninị (ES) lygius.

Išsamiau įvertintas populiariausias frazès „klimato kaita“ paieškos sistemose užklausą atitinkantis rezultatas - Vikipedija straipsnis (lt.wikipedia.org/wiki/Klimato_kaita). Ivertinta puslapio peržiūrų dinamika nuo 2009 iki $2015 \mathrm{~m}$. bei sezoniniai peržiūrų skirtumai.

Tolimesnei analizei pasirinkti penki tinklalapiai organizacijų, kurios tiesiogiai siejasi su informacijos apie KK rinkimu, saugojimu bei pateikimu: Lietuvos Respublikos aplinkos ministerijos (AM), Aplinkos apsaugos agentūros prie Aplinkos ministerijos (AAA), Lietuvos hidrometeorologijos tarnybos prie Aplinkos ministerijos (LHMT), ES Europos aplinkos agentūros (EEA) ir NVO „Aplinkosaugos koalicijos“ (AK). AM ir jai pavaldžios institucijos (AAA ir LHMT) yra tiesiogiai atsakingos už klimato kaitos politiką ir informacijos sklaidą Lietuvoje. EEA - tai pagrindinè ES aplinkosauginè organizacija, apibendrinanti ir skelbianti informaciją apie KK visomis ES kalbomis. AK yra vienintelè Lietuvoje nevyriausybinių aplinkosauginių organizacijų koalicija, vykdanti su klimato kaita susijusias iniciatyvas. Tinklalapiuose pateikta informacija apie KK įvertinta bendrais bruožais atsižvelgiant $\dot{i}$ tai, ar yra klimato kaitos skiltis pirmajame puslapyje; ar pateikiamos iliustracijos; kaip dažnai atnaujinama informacija; ar yra išorinès nuorodos; kokia yra tinklalapio paskirtis ir vyraujanti tematika.

Be penkių tinklalapių pagrindiniuose puslapiuose esančių nuorodų, informacija apie KK taip pat pateikiama naujienų pavidalu. Vertinant naujienas skaičiuojamas komunikacinių žinučių, susijusių su klimato kaita, skaičius. Naujienų dinamikos analizè atlikta nuo 2002 (arba informacijos pateikimo pradžios) iki 2015 m. pabaigos. Kartu ivvertinami naujienų apie KK sezoniniai skirtumai ir dažnis. Detaliau analizuojama naujienų struktūra pagal informacijos sąsajas, aprèptį, paskirti bei paskelbimo laiką ir kilmę. Papildomai ịvertintas naujienų pasikartojimo dažnis socialinio tinklo paskyroje Facebook (www.facebook.com/ klimatokaita) nuo $2013 \mathrm{~m}$. spalio iki $2015 \mathrm{~m}$. gruodžio mèn. Šis AK kuruojamas puslapis yra vienintelis atitinkantis užklausą „klimato kaita“ paskyroje Facebook. 
2 lentelè. Galimi atsakymų variantai ị klausimus, susijusius su frazès „klimato kaita“, paieška internete Table 2. Possible answers for the questions related to search results of phrase 'climate change'

\begin{tabular}{|c|c|c|}
\hline $\begin{array}{l}\text { Klausimas } \\
\text { (ir trumpas } \\
\text { apibūdinimas) } \\
\text { Question } \\
\text { (and short } \\
\text { description) }\end{array}$ & $\begin{array}{l}\text { Galimi atsakymai } \\
\text { Possible answers }\end{array}$ & $\begin{array}{l}\text { Atsakymų interpretacija } \\
\text { Interpretation of answers }\end{array}$ \\
\hline \multirow{6}{*}{$\begin{array}{l}\text { Kas? } \\
\text { (Informacijos } \\
\text { autorius) } \\
\quad \text { Who? } \\
\text { (Affiliation of } \\
\text { information) }\end{array}$} & $\begin{array}{l}\text { Vyriausybinis } \\
\text { Government }\end{array}$ & \multirow{6}{*}{$\begin{array}{l}\text { Interneto puslapiai pagal autorystę gali būti: vyriausybiniai - visi oficialūs } \\
\text { valstybiniai puslapiai; NVO - visi nevyriausybinių organizacijų puslapiai; } \\
\text { aplinkos projektai (aplinkosauginiai projektai) - mokslinių-edukacinių } \\
\text { projektų specializuoti puslapiai; visuomeniniai - puslapiai skurti arba } \\
\text { palaikomi piliečių iniciatyva (Vikipedija, Facebook, ìvairūs BLOGai); } \\
\text { žiniasklaida - internetinės žiniasklaidos priemonès; kita - su KK tiesiogiai } \\
\text { nesusiję puslapiai (vaizdai, videoirašai, enciklopedijos, žodynai). } \\
\text { Affiliation of the website authorities could be: Governmental - all govern- } \\
\text { mental sites; NGOs - all non-governmental sites; Env. project (environmen- } \\
\text { tal project) - scientific-educational project specific site; Social nets - sites } \\
\text { supported by public initiative (Wikipedia, Facebook, blogs); Media - all in- } \\
\text { ternet media sources; Other - indirectly related to climate change (images, } \\
\text { video, encyclopaedia, thesaurus). }\end{array}$} \\
\hline & $\mathrm{NVO} / \mathrm{NGOs}$ & \\
\hline & $\begin{array}{c}\text { Aplinkos projektas } \\
\text { Env. project }\end{array}$ & \\
\hline & $\begin{array}{l}\text { Visuomeninis } \\
\text { Social nets }\end{array}$ & \\
\hline & $\begin{array}{l}\text { Žiniasklaida } \\
\text { Media }\end{array}$ & \\
\hline & Kita / Other & \\
\hline \multirow{4}{*}{$\begin{array}{l}\text { Kur? } \\
\text { (Informacijos } \\
\text { aprèptis) } \\
\text { Where? } \\
\text { (Coverage of } \\
\text { information) }\end{array}$} & Globalus / Global & \multirow{4}{*}{$\begin{array}{l}\text { Interneto puslapiuose pateikiama skirtingo geografinio masto informacija: } \\
\text { globali - susijusi su visu pasauliu, regioninè - susijusi su ES, vietinè - susi- } \\
\text { jusi su Lietuva; arba visu jų mišinys. } \\
\text { Geographical coverage of information could be: global - including whole } \\
\text { world; regional - EU level; local - Lithuania; mix of all levels. }\end{array}$} \\
\hline & $\begin{array}{l}\text { Regioninis } \\
\text { Regional }\end{array}$ & \\
\hline & Lokalus / Local & \\
\hline & Ivairus / Mixture & \\
\hline \multirow{3}{*}{$\begin{array}{l}\text { Kada? } \\
\text { (Informacijos } \\
\text { naujumas) } \\
\text { When? } \\
\text { (Novelty of } \\
\text { information) } \\
\end{array}$} & $\geq 2014$ & \multirow{3}{*}{$\begin{array}{l}\text { KK informacija yra dinamiška, turi būti nuolatos peržiūrima ir atnauji- } \\
\text { nama. Naujai atnaujinta informacija laikytina pastarujų trejų metų; 4-6 } \\
\text { metų - vidutiniškai nauja; daugiau kaip } 6 \text { metus neatnaujinta - pasenusi. } \\
\text { CC is a very dynamic medium and all-time refreshment of information is } \\
\text { needed: new information up to } 3 \text { years; medium - 4-6 years; and old - >6 } \\
\text { years. }\end{array}$} \\
\hline & 2011-2013 & \\
\hline & $\leq 2010$ & \\
\hline \multirow{3}{*}{$\begin{array}{l}\text { Kodèl? } \\
\text { (Informacijos } \\
\text { paskirtis) } \\
\text { Why? } \\
\text { (Purpose of } \\
\text { information) }\end{array}$} & $\begin{array}{l}\text { Informacija } \\
\text { Information }\end{array}$ & \multirow{3}{*}{$\begin{array}{l}\text { Interneto puslapiuose pateikiama informacija siekiama: tik informuoti } \\
\text { apie îvyki, faktą; mokyti aiškinant ir apibūdinant; gilintis ị sudètingesnius } \\
\text { mokslinius aspektus. } \\
\text { Purpose of information could be divided into: only to inform about; educate } \\
\text { on process; and deeper scientific proof. }\end{array}$} \\
\hline & $\begin{array}{l}\text { Edukacija } \\
\text { Education }\end{array}$ & \\
\hline & Mokslas / Science & \\
\hline \multirow{3}{*}{$\begin{array}{l}\text { Kaip? } \\
\text { (Informacijos } \\
\text { kilmé) } \\
\text { How? } \\
\text { (Origin of } \\
\text { information) }\end{array}$} & $\begin{array}{l}\text { Originalus } \\
\text { Original }\end{array}$ & \multirow{3}{*}{$\begin{array}{l}\text { Interneto puslapiuose pateikiama labai skirtingai atsiradusi informacija. Ji } \\
\text { gali būti originali, parengta pačių autorių; nukopijuota, išversta, kitaip adap- } \\
\text { tuota iš ịvairių šaltinių; turèti tiek originalių, tiek ir adaptuotų dalių. } \\
\text { Origin of information could vary: from originally created for website to cop- } \\
\text { ied, translated from other sources, through halforiginal half adaptation form. }\end{array}$} \\
\hline & $\begin{array}{l}\text { Adaptuotas } \\
\text { Adaptation }\end{array}$ & \\
\hline & Maišytas / Mixture & \\
\hline \multirow{3}{*}{$\begin{array}{l}\text { Kiek? } \\
\text { (Informacijos } \\
\text { kiekis) } \\
\text { How much? } \\
\text { (Amount of } \\
\text { information) }\end{array}$} & $\begin{array}{c}\text { Platus } \\
\text { Wide range }\end{array}$ & \multirow{3}{*}{$\begin{array}{l}\text { Interneto puslapiuose pateikiamas labai skirtingas informacijos kiekis: } \\
\text { tai gali büti pavienis straipsnis; nedidelè informacija, tačiau turinti daug } \\
\text { išoriniu nuorodų; daug ir plačiai pateikiama. } \\
\text { Amount of information could vary: from one separated piece to a wide range } \\
\text { of information inside the same webpage, through one piece with external } \\
\text { links to sources. }\end{array}$} \\
\hline & $\begin{array}{l}\text { Su nuoroda } \\
\text { With links }\end{array}$ & \\
\hline & Pavienis / Small & \\
\hline
\end{tabular}




\section{REZULTATAI}

\section{Klimato kaita interneto paieškos sistemose}

Iš viso per 6 kartus i populiariausiujų dešimtuką pateko 19 skirtingu interneto puslapių (3 lentelè), tačiau kai kurie jų (ES komisijos ir EEA puslapiai) dubliuojasi. Palyginus frazès "klimato kaita“ užklausos apie populiariausiųjų dešimtuką rezultatus, matyti, kad per daugiau kaip pusantrų metu atsinaujino daugiau nei $60 \%$ pozicijų. Nuolat i populiariausiujų dešimtuką pateko tik trys puslapiai - lietuviškoji Vikipedija, Google vaizdai ir

3 lentelè. Interneto puslapių, patekusių ị frazès „klimato kaita“ populiariausiųjų dešimtuką (Google paieška), vieta nuo $2015 \mathrm{~m}$. birželio $4 \mathrm{~d}$. iki $2016 \mathrm{~m}$. rugsẻjo $20 \mathrm{~d}$. Populiariausiųjų dešimtuko rezultatų skaičiai pajuodinti, populiariausiųjų trejetuko rezultatai pasviri. Portalo spalvos intensyvumas atspindi patekimu $i$ populiariausiųjų dešimtuką dažnị (daugiau nei 3 kartus): 6 kartus; 5 kartus; 4 kartus

Table 3. The place of websites in top10 results (Google search) from 04.06.2015 to 20.09.2016. The numbers in top 10 position are bolded; top 3 position in italic; the rate of recurrence in top10 position (more than 3 times) presented in intensity of cell colour: 6 times ; 5 times ; 4 times

\begin{tabular}{|c|c|c|c|c|c|c|}
\hline \multirow[b]{2}{*}{$\begin{array}{l}\text { Interneto puslapio prieskyra } \\
\text { Assignment to internet website }\end{array}$} & \multicolumn{3}{|c|}{2016} & \multicolumn{3}{|c|}{2015} \\
\hline & $\begin{array}{l}\text { ㅇ } \\
\text { aे }\end{array}$ & $\frac{1}{20}$ & $\begin{array}{l}\vec{J} \\
\overrightarrow{0}\end{array}$ & $\hat{ヘ}$ & $\begin{array}{l}\dot{0} \\
\dot{8}\end{array}$ & $\begin{array}{l}\not{\delta} \\
\text { ป }\end{array}$ \\
\hline $\begin{array}{c}\text { Lietuvos hidrometeorologijos tarnyba (LHMT) } \\
\text { Lithuanian Hydrometeorological Service }\end{array}$ & 1 & 6 & 10 & 24 & 5 & 4 \\
\hline Lietuviškoji Vikipedija / Wikipedia (Lithuania) & 2 & 1 & 1 & 1 & 1 & 1 \\
\hline $\begin{array}{l}\text { ES komisija (ES): klimato kaitos pasekmès } \\
\text { EU Commission (ES): climate change consequence }\end{array}$ & 3 & - & - & - & - & - \\
\hline $\begin{array}{l}\text { Europos komisija: klimato kaita } \\
\text { EU Commission: climate change }\end{array}$ & 4 & 2 & 3 & 3 & - & - \\
\hline $\begin{array}{l}\text { Europos aplinkos agentūra (EEA): klimato kaita } \\
\text { European Environmental Agency: climate change }\end{array}$ & 5 & 3 & 2 & 2 & 2 & 2 \\
\hline $\begin{array}{l}\text { Europos aplinkos agentūra (EEA): klimato kaita } 2 \\
\text { European Environmental Agency: climate change } 2\end{array}$ & 6 & 148 & 4 & 4 & - & - \\
\hline $\begin{array}{l}\text { ES komisija (ES): klimato kaitos priežastys } \\
\text { EU Commission (ES): climate change cause }\end{array}$ & 7 & 4 & - & - & - & - \\
\hline
\end{tabular}

\begin{tabular}{ccccccc}
\hline Lietuvos energetikos institutas (LEI) / Lithuanian Energy Institute & $\mathbf{8}$ & $\mathbf{9}$ & 21 & $\mathbf{7}$ & - & - \\
\hline $\begin{array}{c}\text { Google vaizdai: klimato kaita / Google images: climate change } \\
\text { Baltijos aplinkos forumas (BEF) / Baltic Environmental Forum }\end{array}$ & $\mathbf{9}$ & $\mathbf{5}$ & $\mathbf{6}$ & $\mathbf{9}$ & $\mathbf{4}$ & $\mathbf{3}$ \\
\hline $\begin{array}{c}\text { Darnus vystymasis: projektas / Sustainable Development: project } \\
\text { Vytauto Didžiojo universitetas (VDU) }\end{array}$ & 16 & $\mathbf{7}$ & $\mathbf{8}$ & $\mathbf{6}$ & $\mathbf{6}$ & $\mathbf{6}$ \\
\hline $\begin{array}{c}\text { Vytautas Magnus University } \\
\text { Ekokarta: projektas }\end{array}$ & 18 & $\mathbf{1 0}$ & - & - & - & - \\
\hline Eco generation: project & - & - & $\mathbf{5}$ & $\mathbf{5}$ & $\mathbf{3}$ & $\mathbf{5}$ \\
\hline $\begin{array}{c}\text { Aplinkos apsaugos agentūra (AAA) } \\
\text { Environmental Protection Agency }\end{array}$ & 17 & 14 & $\mathbf{9}$ & $\mathbf{1 0}$ & $\mathbf{9}$ & 11 \\
\hline AIVIKS & 19 & 12 & 11 & 11 & $\mathbf{8}$ & 13 \\
\hline Delfi.lt tema: klimato kaita / Delfi.lt theme: climate change & 37 & 16 & 12 & 14 & $\mathbf{1 0}$ & $\mathbf{7}$ \\
\hline Delfi.lt video: mokslo sriuba / Delfi.lt video: science soup & 88 & 73 & 13 & 13 & 34 & $\mathbf{8}$ \\
\hline $\begin{array}{c}\text { Žaliasis pasaulis: klimato kaita ir Lietuva } \\
\text { The Green World: climate change and Lithuania }\end{array}$ & 101 & - & 49 & 26 & 18 & $\mathbf{9}$ \\
\hline
\end{tabular}

Lietuvos mokslo taryba (LMT) / Research Council of Lithuania $\quad \begin{array}{llllll}87 & 37 & 29 & 35 & 35 & \mathbf{1 0}\end{array}$ 
EEA. Dalis puslapių prarado populiarumą - Žaliasis pasaulis, DELFI video, Lietuvos mokslo taryba; kiti, priešingai, ji igijo - Lietuvos energetikos institutas, Vytauto Didžiojo universitetas. Pažymètina, kad tarp populiariausiųjų nepateko Aplinkos ministerijos puslapis, o Aplinkos apsaugos agentūra ir jungtinis informacijos portalas AIVIKS balansuoja ties 10 pozicija. Tik Lietuvos hidrometeorologijos tarnybos interneto svetainè nuolat būna tarp populiariausiųjų. Apie $50 \%$ visų šaltinių, patekusių i̇ populiariausiųjų dešimtuką, yra ES komisijos ir EEA puslapiai. Remiantis tuo, kad pirmojo paieškos puslapio rezultatams tenka 9 iš 10 peržiūrų, galima teigti, kad Lietuvos gyventojai daugiausia remiasi ne lietuviškų šaltinių informacija. Dažnai lankomi NVO puslapiai - Baltijos aplinkos forumas, Darnus vystymasis, Ekokarta.

Kada? Nuolatinis žinių apie klimato kaitą atnaujinimas yra ypač svarbus procesas norint užtikrinti informacijos kokybę. Vertinimas pagrịstas atnaujinimo analize, t. y. datomis, kada informacija puslapyje buvo atnaujinta paskutini kartą, nors ir formaliai (pvz., Vikipedija). Deja, nauja (ne vèliau kaip $2014 \mathrm{~m}$. paskelbta) informacija pateikiama tik kiek daugiau nei puseje populiariausiųjų dešimtuko pozicijų (1a pav.). Paieškos sistemoje Google per $30 \%$ informacijos yra itin sena, o naujesnius sistemų Bing ir Yahoo rezultatus lèmè naujienas pateikiančiu portalu (delf.lt, 7broliaimiegantys.wordpress.com, facebook.com/klimatokaita) gausa populiariausiųjų dešimtuke. Pažymètina, kad per tiriamąji laikotarpi visų interneto paieškos sistemų naujumas augo ir pasieké $70-80 \%$.

Kiek? Rezultatai apie klimato kaitą turètų būti pateikiami ne pavienių šaltinių. Reikètų, kad turètų bent jau papildomų nuorodų $\mathfrak{i}$ išorinius šaltinius. Apie $80 \%$ populiariausiųjų dešimtuko rezultatų atitiko šiuos kriterijus ( $1 \mathrm{~b}$ pav.), tačiau visose paieškos sistemose vis dar pasitaiko pavienių nuorodų, t. y. kai informacija nèra susijusi su likusiu puslapio turiniu. Google vèl šiek tiek atsilieka nuo paieškos sistemų Bing ir Yahoo dèl ilgai populiariausiųjų dešimtuko pozicijose užsilaikančių, seną informaciją pateikiančių šaltinių (Europos komisija, Lietuvos energetikos institutas, Ekokarta, Darnus vystymasis). Paieškos sistemose Bing ir Yahoo pastebima teigiama plataus informacijos pobūdžio pateikimo dinamika, tai lemia nuolatos atnaujintą medžiagą teikiančių šaltinių gausejjimo tendencija (delfi.lt; 7broliaimiegantys.wordpress.com; facebook.com/klimatokaita).

Kas? Labai sunku apibrèžti informacijos autorių grupių paskirstymą tarp populiariausiųjų dešimtuko. Atskiruose informaciją suteikiančiu organizacijų tipuose išryškejja didžiausi skirtumai tarp interneto paieškos sistemų Google, Bing ir Yahoo rezultatu (1c pav.). Net 48 \% Google rezultatų tenka valstybinių institucijų, tiek vietinių, tiek ir Europiniu tinklalapiams - AM, AAA, LHMT, ES, EEA. Net 47 \% Yahoo šaltinių priskiriami kategorijai "kita“ - YouTube, vaizdai, videoįrašai. Sistema Bing išsiskiria visuomeninių puslapių (33 \%) gausa - 7broliaimiegantys, Facebook ir kt. Paieškos sistemose Google ir Bing pastebima valstybinių institucijų tinklalapių patekimo ị populiariausiųjų dešimtuką augimo tendencija.

Kodèl? Būtu idealu, kad visi, patenkantys it populiariausiųjų dešimtuką, ne tik informuotų, bet ir mokytų apie klimato kaitą. Informacijos ir edukacijos santykis sistemose Google ir Yahoo yra maždaug vienodas (1d pav.), o Bing edukacijai tenka tik $24 \%$. Bing rezultatai daugiausia remiasi žiniasklaidos ir vaizdus (YouTube) pateikiančiomis nuorodomis, kai, ypač Google, orientuojasi i Europos ir aplinkosauginių projektų puslapius. Dar vienas bruožas, būdingas lietuviškai informacijai apie klimato kaitą, yra tai, kad i populiariausiųjų dešimtuką nepatenka su mokslu susijusios interneto nuorodos (su išlyga šiai kategorijai galima būtų priskirti Lietuvos hidrometeorologijos tarnybos puslapi). Per tyrimo laikotarpi edukacijos ir informacijos santykis interneto paieškos sistemose beveik nekito.

Kaip? Lietuviškuose šaltiniuose vyrauja adaptuota ar maišyta, t. y. daugiausia ne pačių sukurta, informacija apie klimato kaitą (1e pav.), paieškos sistemoje Google originalių šaltinių, paremtų ES ir NVO puslapių informacija, yra tris kartus daugiau nei Bing ir Yahoo, kurie daugiausia remiasi žiniasklaidos priemonių ar vaizdus perteikiančių puslapių informacija. Taip pat pastebima, kad Google originalios informacijos kiekis nežymiai auga ir tyrimo pabaigoje pasieke $40 \%$.

Kur? Kadangi klimato kaitos procesas apima visas erdves, apie ji reikia informuoti nuo vietinio iki globalaus lygmens. Bing ir Yahoo remiasi plačiai apimančia, nauja, apibendrinta bei adaptuota 


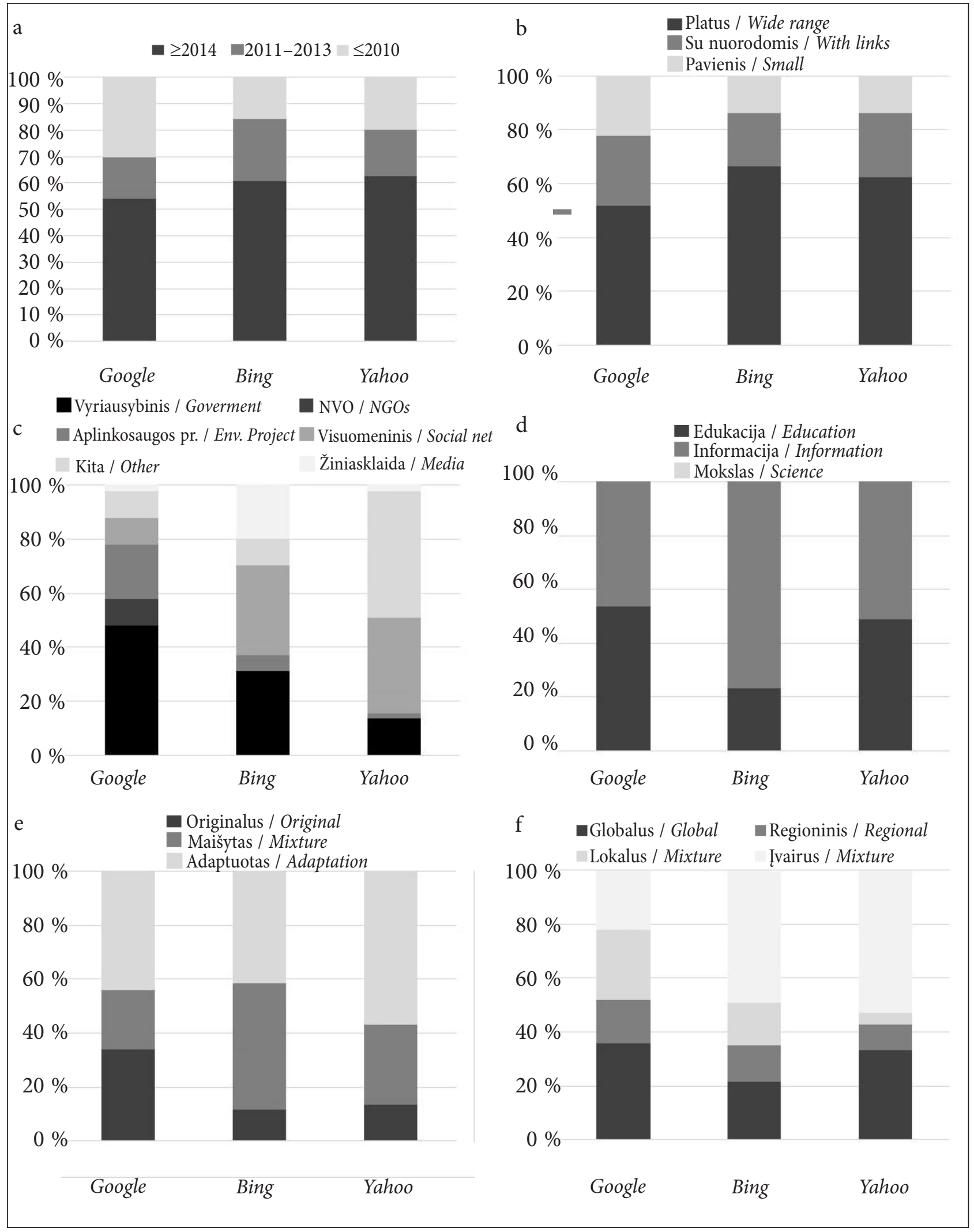

1 pav. Frazès „klimato kaita“ populiariausiųjų dešimtuko rezultatų pasiskirstymas (\%) Google, Bing ir Yahoo interneto paieškos sistemose pagal skirtingas informacijos analizès kategorijas (žr. 1 lentelę): a - kada; b - kiek; c - kas; d - kodèl; e - kaip; f - kur. Apskaičiuota pagal 5 matavimų vidurkị nuo 2015 m. birželio 4 d. iki 2016 m. rugsèjo 20 d. Fig. 1. The distribution (\%) of phrase 'climate change' in top10 results (Google, Bing and Yahoo internet search engines) according to related categories (see Table 1): $a$ - when, $b$ - how much, $c-$ who, $d-w h y, e-h o w, f-$ where. The average of five different searches from 04.06.2015 to 20.09.2016 
informacija, net $50 \%$ rezultatų aprèpia visus erdvinius lygmenis (1f pav.), kai Google pateikta informacija yra per daug segmentuota, t. y. visi erdviniai lygiai aprépiami panašiai. Teigiamai galima ịvertinti Google paieškos vietinị lygmenị apimančių rezultatų sumažejimą nuo 40 iki $20 \%$.

Išsamesné populiariausiųų trejetuko rezultatų analizè parodè, kad visuomeniniai puslapiai (Vikipedija, Facebook, YouTube) užima daugiau kaip $50 \%$ visų paieškos rezultatų (2 pav.). Žiniasklaidos puslapių gausa būdinga Bing paieškos rezultatams, o didžioji dalis oficialių valstybinių nuorodų tenka ES ir EEA interneto puslapiams paieškos sistemoje Google. Pastebimas itin menkas NVO puslapių skaičius (2\%) populiariausiųjų trejetuke.

\section{Informacinis lyderis - Vikipedija}

Straipsnio apie klimato kaitą lietuviškoje Vikipedijoje (lt.wikipedia.org/wiki/Klimato_kaita) reitingas yra aukščiausias tarp visų interneto paieškos sistemose esančių rezultatų. Nuo 2015 m. vasario 4 d. iki 2016 m. rugsèjo 20 d. per šešis kartus Vikipedija tik po kartą atsidūrè antroje paieškos rezultatų vietoje sistemose Google, Bing ir Yahoo.
Vertinant tarptautini Vikipedijos kontekstą straipsniai apie KK Baltijos jūros regiono valstybèse egzistuoja visomis kalbomis, išskyrus baltarusių (Kažys, 2016). Nors straipsnių yra daugeliu kalbų, juose pateikiamas skirtingas informacijos kiekis (3 pav.). Daugiausia informacijos apie klimato kaitą randama angliškajame variante, o lietuviškai pateiktos informacijos yra net septynis kartus mažiau. Mažiau informacijos pateikiama tik švedų ir latvių (naujas ir beveik neturintis jokios informacijos straipsnis) kalbomis. Dar viena skirtingo informacijos kiekio priežastis, kad frazė „klimato kaita“ skirtingomis kalbomis ivairiai vartojama ir interpretuojama. Pavyzdžiui, lietuviškai akcentuojama tik dabartinė žmogaus sukelta klimato kaita, kai straipsnis rusų kalba remiasi gamtinėmis priežastimis ir klimato svyravimų istorija. Angliški ir ukrainietiški tekstai apima visus aspektus.

Vertinant peržiūras lietuviškasis variantas užima 2822 vietą tarp visų Vikipedijos straipsnių. Iš 2016 m. sausio mèn. duomenų matyti, kad puslapis buvo peržiūrètas 265 kartus. Mažiau peržiūrèti puslapiai tik ukrainiečių ir estų kalbomis, atitinkamai 251 ir 216 karto. Tuo tarpu situacija yra

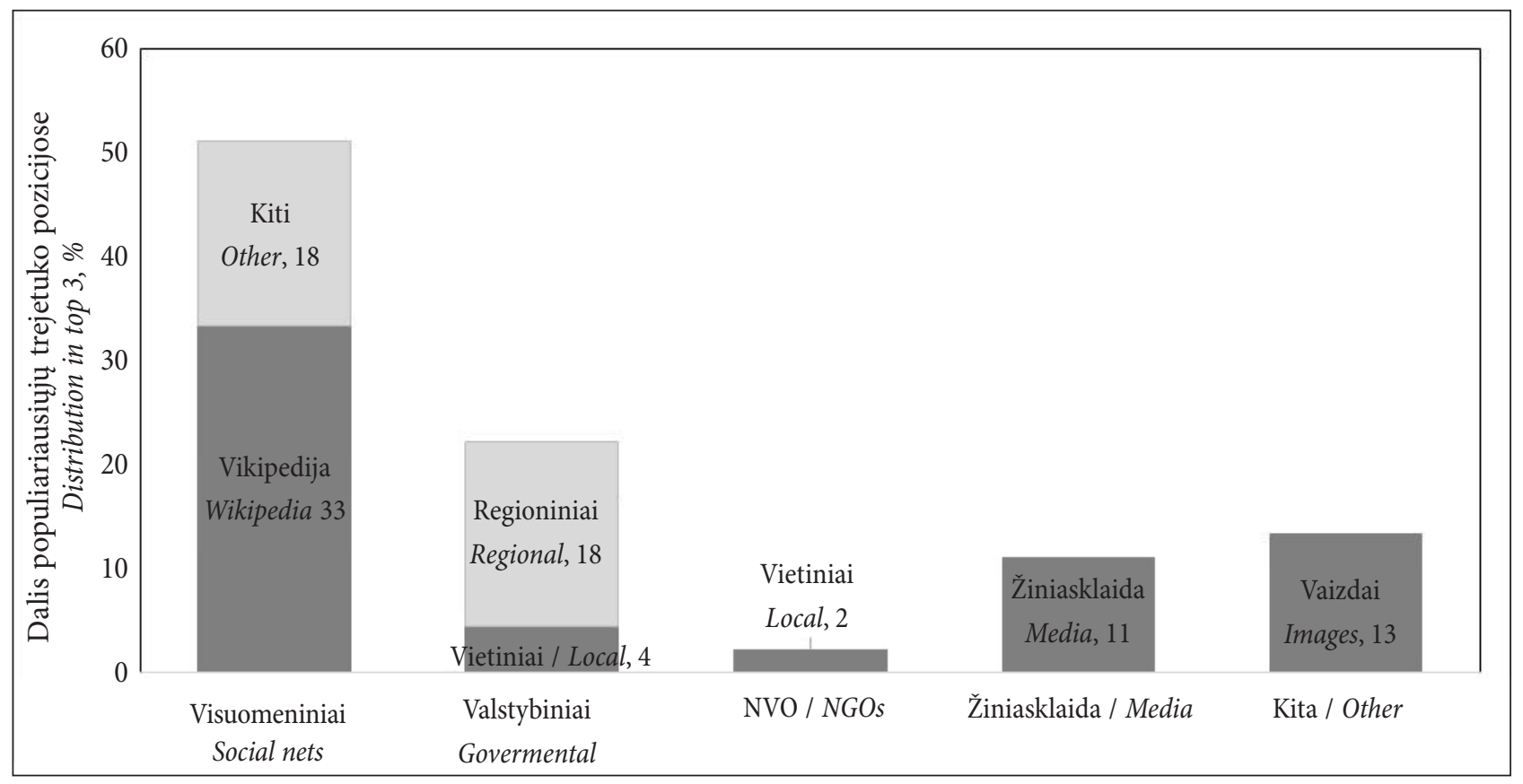

2 pav. Frazès „klimato kaita“ populiariausiųjų trejetuko pozicijų pasiskirstymas (\%) interneto paieškos sistemose (Google, Bing, Yahoo) tarp skirtingų autorių grupių. Apskaičiuota pagal penkias užklausas nuo 2015 m. birželio 4 d. iki $2016 \mathrm{~m}$. rugsejo $20 \mathrm{~d}$.

Fig. 2. The distribution (\%) of the phrase 'climate change' in top3 results in internet search engines (Google, Bing, Yahoo) among different affiliation groups. The average of five different searches from 04.06.2015 to 20.09.2016 


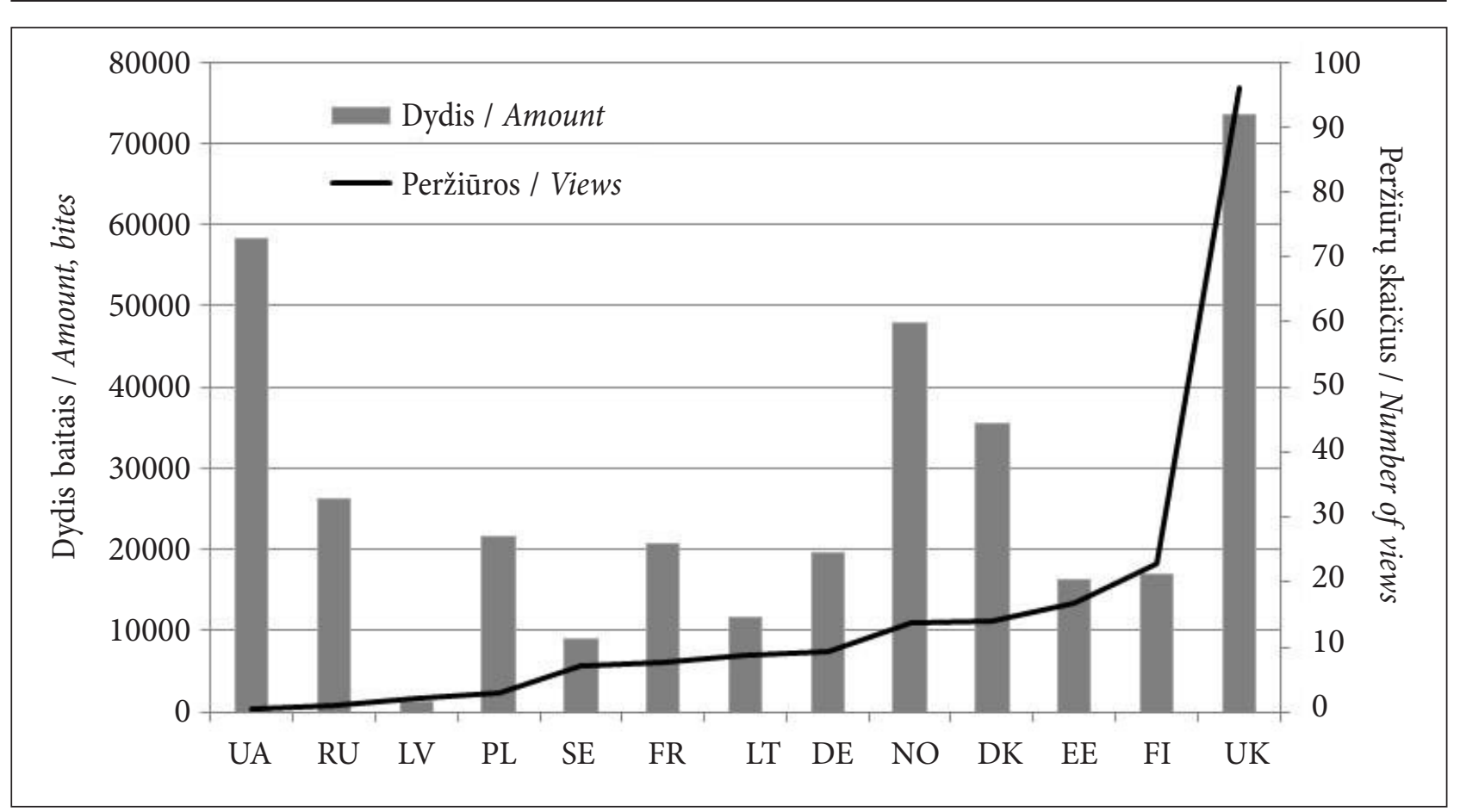

3 pav. Temos „klimato kaita“ Vikipedija portale dydis (baitais) ir peržiūrų skaičius (30 dienų / 100 tūkst. gyv.) skirtingomis kalbomis: DE - Vokietija, DK - Danija, EE - Estija, FI - Suomija, FR - Prancūzija, LT - Lietuva, LV - Latvija, NO - Norvegija, PL - Lenkija, RU - Rusija, SE - Švedija, UA - Ukraina, UK - Jungtinè Karalyste (pagal skirtingų šalių wikipedia.org duomenis, žiūrèta 201609 20)

Fig. 3. Topic 'climate change' content amount (in bites) and number of views (30 days / 100 ths. inhabitants) on Wikipedia in different countries: DE - Germany, DK - Denmark, EE - Estonia, FI - Finland, FR - France, LT - Lithuania, LV - Latvia, NO - Norway, PL - Poland, RU - Russia, SE - Sweden, UA - The Ukraine, UK - The United Kingdom (according to Wikipedia.org information from different countries, accessed 2009 2016)

geresnè vertinant puslapio peržiūras, tenkančias 100 tūkst. šalies gyventojų (3 pav.). Tarp Baltijos regiono valstybių lietuviškajam puslapiui tenka 6 vieta, o neabejotinu lyderiu yra suomių kalba pateiktas straipsnis $(22,7$ peržiūros 100 tūkst. gyventoju).

Lietuviškasis straipsnio variantas sukurtas 2009 m. lapkričio mèn., kai angliškasis atsirado 2003 m., o Baltijos jūros regiono daugeliu kalbų straipsniai parašyti 2004-2006 metais. Stebint straipsnio peržiūrų nuo 2009 iki 2015 m. dinamiką matyti, kad jų skaičius augo iki 2011 m., véliau stabilizavosi, o nuo $2013 \mathrm{~m}$. pradejo mažèti (4a pav.). Kaip galimo augimo priežastis galima ¿̇vardyti plačios Jungtinių Tautų klimato kaitos konferencijos COP15 renginio, vykusio Kopenhagoje, kampanijos atgarsius ir iš esmès naujo informacijos šaltinio atsiradimą Vikipedijoje. Prasidejęs nuosmukis sietinas su tuo, kad nuo $2012 \mathrm{~m}$. puslapis beveik neatnaujintas.

Taip pat egzistuoja aiški sezoninè interneto puslapio peržiūros struktūra (4b pav.). Mažiausia peržiūrų tenka vasaros sezonui ir naujametiniam laikotarpiui, kai daugelis žmonių atostogauja ir skiria daugiau dèmesio laisvalaikiui. Pikas pasiekiamas kovo-gegužès ir lapkričio mėnesiais. Aiškiai matyti, kad prieš Lietuvos pirmininkavimą ES $2013 \mathrm{~m}$. pirmąji pusmetị puslapio peržiūrų buvo daugiausia, kadangi klimato kaita buvo viena iš prioritetinių pirmininkavimo krypčių.

\section{Informacija svarbiausiuose interneto tinklalapiuose}

4 lentelèje nurodomi pagrindiniai pateiktos informacijos apie klimato kaitą bruožai svarbiausiuose interneto puslapiuose lietuvių kalba. Daugiausia informacijos pateikiama EEA, tačiau ieškant detalesnès informacijos lietuvių kalbą keičia anglų. Pagrindiniame puslapyje nuorodą $\mathfrak{i}$ klimato kaitą pateikia AM, AA ir AK, o LHMT ir EEA nuoroda atrandama tik antrame žingsnyje, tai nèra patogu. Dauguma sąsaju yra su iliustracijomis, išskyrus AM. Pagrindinès informacijos atnaujinimas yra retas arba jo apskritai nèra. Tik trys iš 


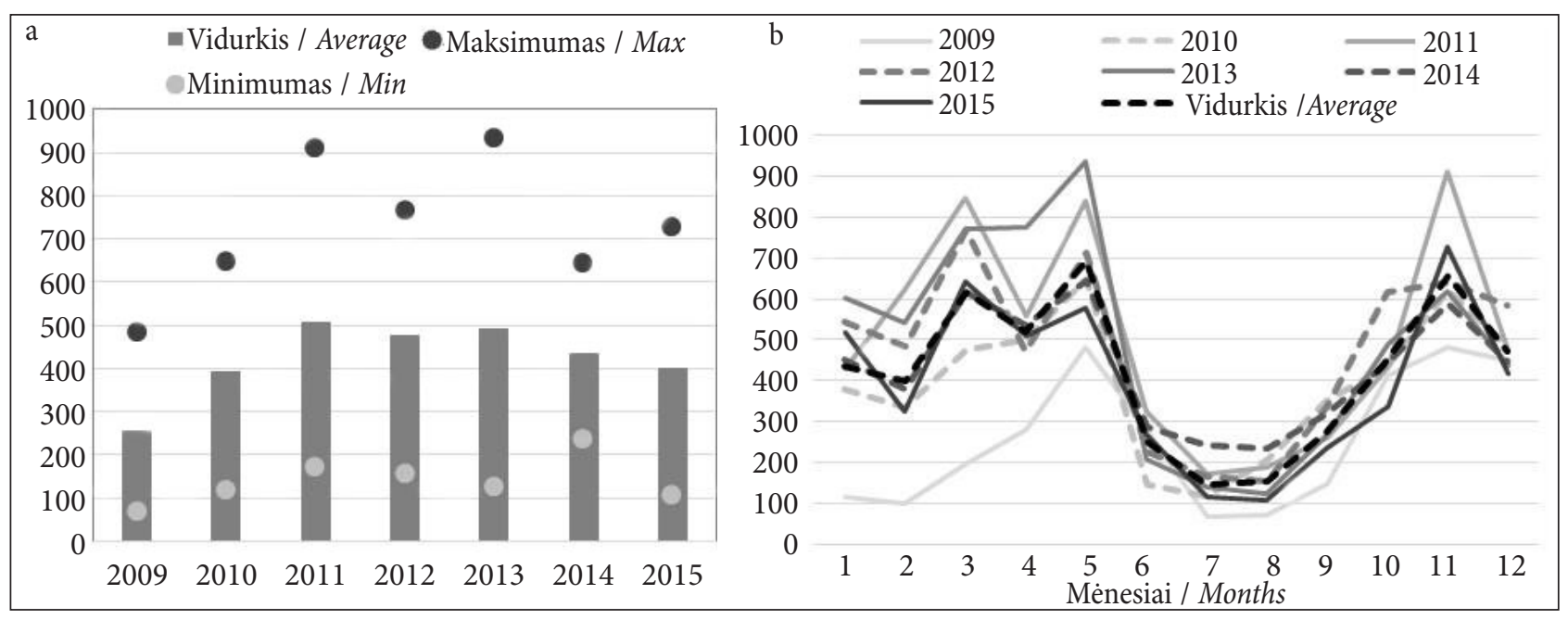

4 pav. Temos „klimato kaita“ peržiūrų skaičiaus pokyčiai per mėnesị lietuviškoje Vikipedijoje 2009-2015 m.: tarp metų (a) ir tarp mènesių (b)

Fig. 4. Inter-annual (a) and intra-annual (b) number of views of topic 'climate change' on Wikipedia (Lithuania) from 2009 to 2015

4 lentelè. Bendrosios klimato kaitos informacijos palyginimas atsakingu organizacijų interneto puslapiuose: LHMT - Lietuvos hidrometeorologijos tarnyba; AM - Aplinkos ministerija; AAA - Aplinkos apsaugos agentūra; EEA - Europos aplinkos agentūra; AK - Aplinkosaugos koalicija

Table 4. The comparison of basic information about CC between websites of responsible institutions: LHMT - The Lithuanian Hydrometeorological Service; AM - The Ministry of Environment; AAA - The Environmental Protection Agency; EEA - European Environmental Agency; AK - Environmental NGOs Coalition

\begin{tabular}{|c|c|c|c|c|c|}
\hline $\begin{array}{l}\text { Organizacija } \\
\text { Organisation }\end{array}$ & LHMT & $\mathrm{AM}$ & AAA & EEA & $\mathrm{AK}^{*}$ \\
\hline $\begin{array}{l}\text { Tinklalapis } \\
\text { Website }\end{array}$ & www.meteo.lt & www.am.lt & gamta.lt & www.eea.europa.eu/lt & aplinkosauga.lt \\
\hline $\begin{array}{c}\text { Nuoroda } \\
\text { „klimato kaita" } \\
\text { "Climate change” } \\
\text { link }\end{array}$ & $\begin{array}{l}\text { Nera } \\
\text { No }\end{array}$ & $\begin{array}{l}\text { Yra } \\
\text { Yes }\end{array}$ & $\begin{array}{l}\text { Yra } \\
\text { Yes }\end{array}$ & $\begin{array}{l}\text { Nèra } \\
\text { No }\end{array}$ & $\begin{array}{l}\text { Yra } \\
\text { Yes }\end{array}$ \\
\hline $\begin{array}{l}\text { Iliustracijos } \\
\text { Iliustruotinos }\end{array}$ & $\begin{array}{l}\text { Yra } \\
\text { Yes }\end{array}$ & $\begin{array}{l}\text { Nèra } \\
\text { No }\end{array}$ & $\begin{array}{l}\text { Yra } \\
\text { Yes }\end{array}$ & $\begin{array}{l}\text { Yra } \\
\text { Yes }\end{array}$ & $\begin{array}{l}\text { Yra } \\
\text { Yes }\end{array}$ \\
\hline $\begin{array}{c}\text { Informacijos } \\
\text { atnaujinimas } \\
\text { Refreshment }\end{array}$ & $\begin{array}{l}\text { Nèra } \\
\text { No }\end{array}$ & $\begin{array}{l}\text { Retas } \\
\text { Rare }\end{array}$ & $\begin{array}{l}\text { Retas } \\
\text { Rare }\end{array}$ & $\begin{array}{l}\text { Retas } \\
\text { Rare }\end{array}$ & $\begin{array}{l}\text { Nèra } \\
\text { No }\end{array}$ \\
\hline $\begin{array}{l}\text { Išorinès nuorodos } \\
\text { External links }\end{array}$ & $\begin{array}{l}\text { Nèra } \\
\text { No }\end{array}$ & $\begin{array}{l}\text { Yra } \\
\text { Yes }\end{array}$ & $\begin{array}{l}\text { Yra } \\
\text { Yes } \\
\end{array}$ & $\begin{array}{c}\text { Nèra } \\
\text { No }\end{array}$ & $\begin{array}{c}\text { Nera } \\
\text { No }\end{array}$ \\
\hline $\begin{array}{l}\text { Tinklalapio } \\
\text { paskirtis } \\
\text { Attribution }\end{array}$ & $\begin{array}{l}\text { Informacinè } \\
\text { Information }\end{array}$ & $\begin{array}{l}\text { Informacinè } \\
\text { Information }\end{array}$ & $\begin{array}{l}\text { Informacinè- } \\
\text { edukacinè } \\
\text { Information- } \\
\text { education }\end{array}$ & $\begin{array}{c}\text { Informacinè- } \\
\text { edukacinè } \\
\text { Information-education }\end{array}$ & $\begin{array}{l}\text { Informacinè- } \\
\text { edukaciné } \\
\text { Information- } \\
\text { education } \\
\end{array}$ \\
\hline $\begin{array}{l}\text { Vyraujanti } \\
\text { tematika } \\
\text { Prevailing } \\
\text { topics }\end{array}$ & $\begin{array}{l}\text { Fiziniai KK } \\
\text { procesai } \\
\text { Lietuvoje da- } \\
\text { bar ir ateityje } \\
\text { CC physical } \\
\text { basis and CC } \\
\text { in Lithuania }\end{array}$ & $\begin{array}{l}\text { KK politika, } \\
\text { KK } \\
\text { švelninimas } \\
\text { CC politics } \\
\text { and } \\
\text { mitigation }\end{array}$ & $\begin{array}{l}\text { Šiltnamio efektą } \\
\text { sukeliančių dujų } \\
\text { apskaita, } \\
\text { KK švelninimas } \\
\text { GHG accounting } \\
\text { and CC } \\
\text { mitigation }\end{array}$ & $\begin{array}{c}\text { KK politika, KK } \\
\text { švelninimas ir prisitai- } \\
\text { kymas, informavimas } \\
\text { apie KK } \\
\text { CC politics, } \\
\text { mitigation, adaptation } \\
\text { and information }\end{array}$ & $\begin{array}{l}\text { KK politika, } \\
\text { informavimas } \\
\text { apie KK } \\
\text { CC politics and } \\
\text { information }\end{array}$ \\
\hline
\end{tabular}

* remtasi senąja aplinkosauga.lt puslapio versija, paskutinị kartą žiūrèta 20160920. 
penkių interneto puslapių daugiau dèmesio skiria edukacijai. Pažymètina, kad vyrauja KK politikos ir KK švelninimo tematika, o prisitaikymas prie klimato kaitos plačiau aptariamas tik EEA puslapyje.

Greta pagrindinès informacijos visi tinklalapiai teikia naujienas, susijusias su klimato kaita. Naujienos parodo puslapio gyvybingumą ir organizacijos aktyvumą sprendžiant su KK susijusius klausimus. Klimato kaitos naujienos bendrame naujienų sraute sudaro 7-14\%, daugiausia jų aptinkame AAA puslapyje, o mažiausia - EEA puslapyje. Pagrindiniuose puslapiuose didžioji dalis naujienų (44-74 \%) buvo paskelbtos per pastaruosius ketverius metus (2012-2015), tik EEA didžioji dalis naujienų (45\%) tenka 2008-2011 m. Pirmoji informacija lietuvių kalba EEA puslapyje pasirode dar 2002 m. (5 pav.). Nors nuo 2003 m. AM tinklalapis jau turèjo naujienų skiltí, bet pirmoji su KK susijusi informacija pasirodè tik 2005 m. Bendras (AM, AAA ir LHMT) naujienų skaičius augo iki 2009 m., o vèliau èmé staigiai kristi. Tai galima sieti su ekonomine krize ir vy- raujančiomis Aplinkos ministerijos veiklos gairèmis (namu renovacija, sąvartynai, žuvininkystè ir kt.) vadovaujant G. Kazlauskui. 2013 m. naujienu pagausejjimą (ypač AM) galima sieti su Lietuvos pirmininkavimu ES (antrasis metų pusmetis) ir platesniu naujojo ministro V. Mazuronio požiūriu. NVO AK suaktyvejjimas naujienų srityje 2013-2014 m. sietinas su vykdoma projektine veikla, klimato kaitos advokacija bei aktyviu dalyvavimu Jungtinių Tautų klimato kaitos konferencijoje COP19 Varšuvoje. Staigų AK naujienų nuosmuki $2015 \mathrm{~m}$. lèmé tai, kad didžioji dalis informacijos yra pateikiama jų administruojamoje paskyroje Facebook.

Panašiai kaip ir populiariausių interneto paieškos sistemų dešimtuko peržiūrose (4b pav.), taip ir naujienu apie KK sraute egzistuoja sezoniniai skirtumai (6a pav.). Rugpjūčio mèn. naujienu praktiškai nebūna, o didžiausias jų srautas matomas spalio-gruodžio mènesiais. Apjungus AM, AAA ir LHMT duomenis, vidutiniškai per metus paskelbiama 12,4 naujienos arba kas naujieną per mènesí ( $6 \mathrm{~b}$ pav.). Didžiausias indèlis tenka AM

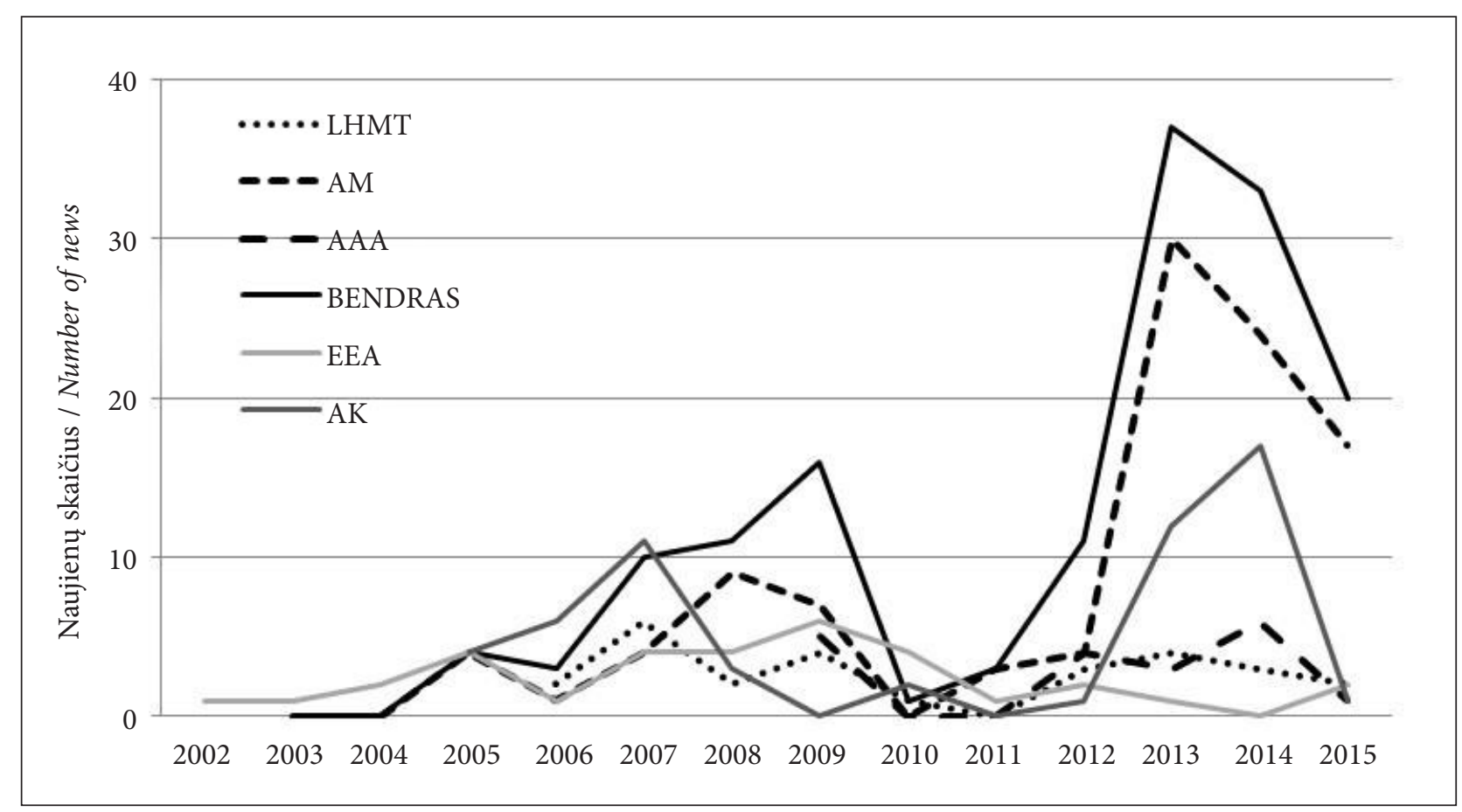

5 pav. Naujienų, susijusių su klimato kaita, kiekio pasiskirstymas pagal metus skirtinguose portaluose: LHMT - Lietuvos hidrometeorologijos tarnyba; AM - Aplinkos ministerija; AAA - Aplinkos apsaugos agentūra; BENDRAS - LHMT+AM+AAA; EEA - Europos aplinkos agentūra; AK - Aplinkosaugos koalicija

Fig. 5. The number of news about climate change in different years on the selected websites: LHMT - The Lithuanian Hydrometeorological Service; AM - The Ministry of Environment; AAA - The Environmental Protection Agency; BENDRAS - LHMT+AM+AAA; EEA - European Environmental Agency; AK - Environmental NGOs Coalition 


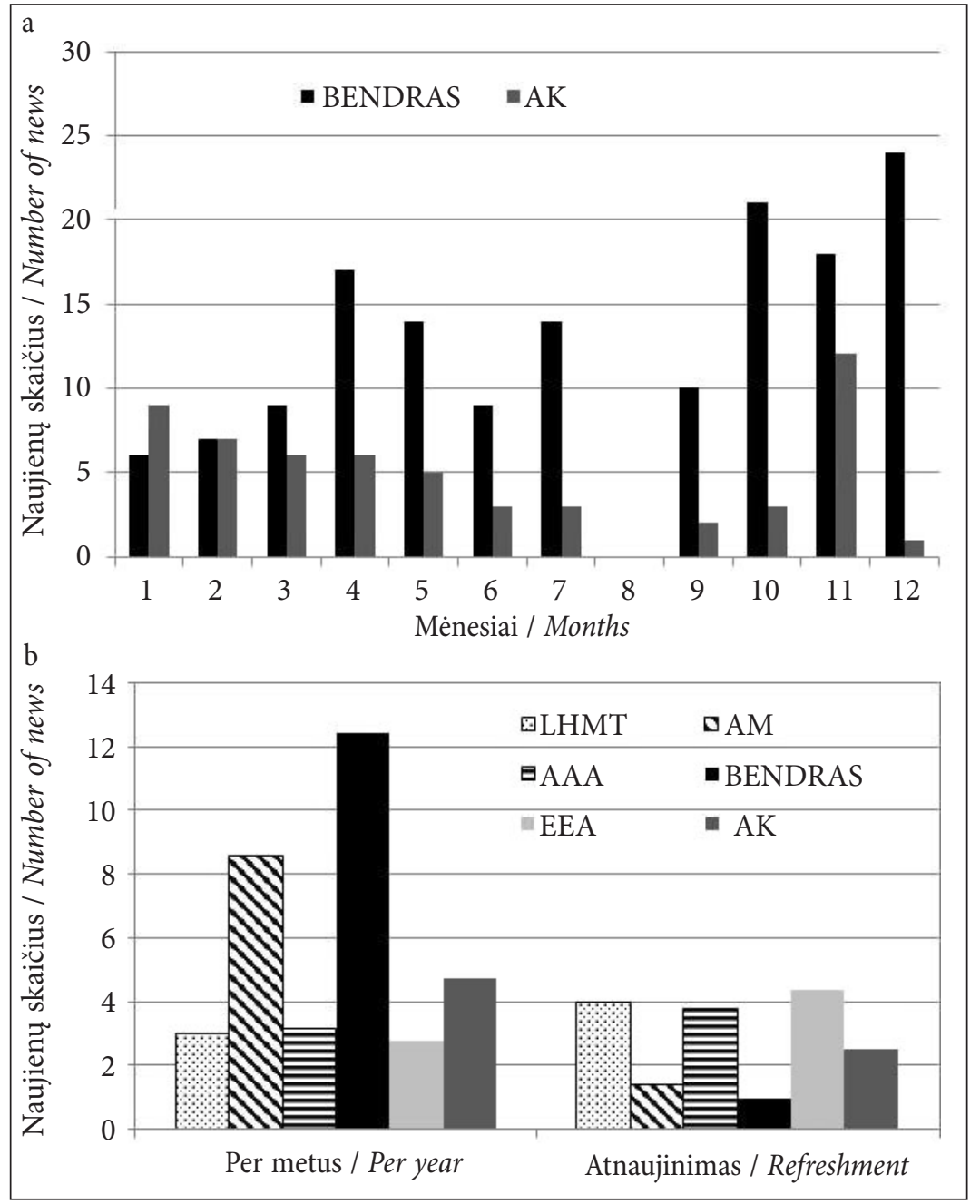

6 pav. Klimato kaitos naujienų kiekio pasiskirstymas per metus (a); vidutinis naujienų skaičius per metus ir atsinaujinimo intervalas ménesiais (b) skirtinguose portaluose (santrumpas žr. 5 pav.)

Fig. 6. The number of news about climate change in different months (a), as well as average number of news per year and monthly refreshment of the news (b) on the selected websites (see Fig. 5 for abbreviations) tinklalapiui. Ilgiausiai naujienų, susijusių su klimato kaita, reikia laukti EEA tinklalapyje - per keturis mènesius.

Detalesnè naujienų apie klimato kaitą, skelbiamų AM, AAA, LHMT ir AK interneto tinklalapiuose, analizè parodè, kad puslapiuose pateikiamos naujienos stipriai siejasi su atstovaujama organizacija (56-91\%), ir tik AAA pateikia daugiau bendro pobūdžio informacijos (58\%). AM ir AAA naujienos orientuotos i ES ir pasaulyje vykstančius ịvykius (38-68\%), o LHMT ir AK koncentruojasi ties Lietuva (48-49\%). Didžioji dalis naujienų suprantamos kaip jau ịvykęs faktas (64-95\%), tik LHMT daugiau informuoja apie būsimą ịvykị (63\%). Taip pat didžioji dalis naujienų yra trumpos, bet sukurtos pačioje organizacijoje (54-86\%), tik AAA daugiausia remiasi kitų pateikiama informacija ( $89 \%$ ).

Dalis AK informacijos apie KK perkelta i paskyrą Facebook. Paieškos sistemose Bing ir Yahoo puslapis nuolatos patenka i populiariausių nuo- rodų dešimtuką (2016 0920 duomenys, 2 vieta), todel yra svarbus informacijos apie KK šaltinis. Tinklalapis atsirado $2013 \mathrm{~m}$. spali, o ji „mégstantys" pažymėjo 543 asmenys. Tenka apgailestauti, kad naujienų, pateikiamų šiame puslapyje, srautas nèra pastovus ( 7 pav.). Didžiausias aktyvumas fiksuotas 2013 m. lapkričio-gruodžio mèn., 2015 m. gruodi ir sietinas su aktyviu AK nariu dalyvavimu Jungtinių Tautų klimato kaitos konferencijų COP19 ir CO21 renginiuose Varšuvoje ir Paryžiuje. Šiuo laikotarpiu naujienos pasiekdavo skaitytojus beveik kiekvieną dieną. Pakankamai pastovus naujienų skaičius per $2014 \mathrm{~m}$. yra AK vykdyto projekto „Aplinkosaugos NVO vaidmens stiprinimas formuojant klimato kaitos politiką" išdava. Taip pat reikia pažymèti, kad paskyroje Facebook pradine informacija pateikiama lietuviškai, tačiau didžioji dalis nuorodų $\mathfrak{i}$ išorinius šaltinius yra anglų kalba. Dažniausiai pasitaikančios nuorodos yra i youtube.com, theguardian.com ir grynas.delfi.lt puslapius. 


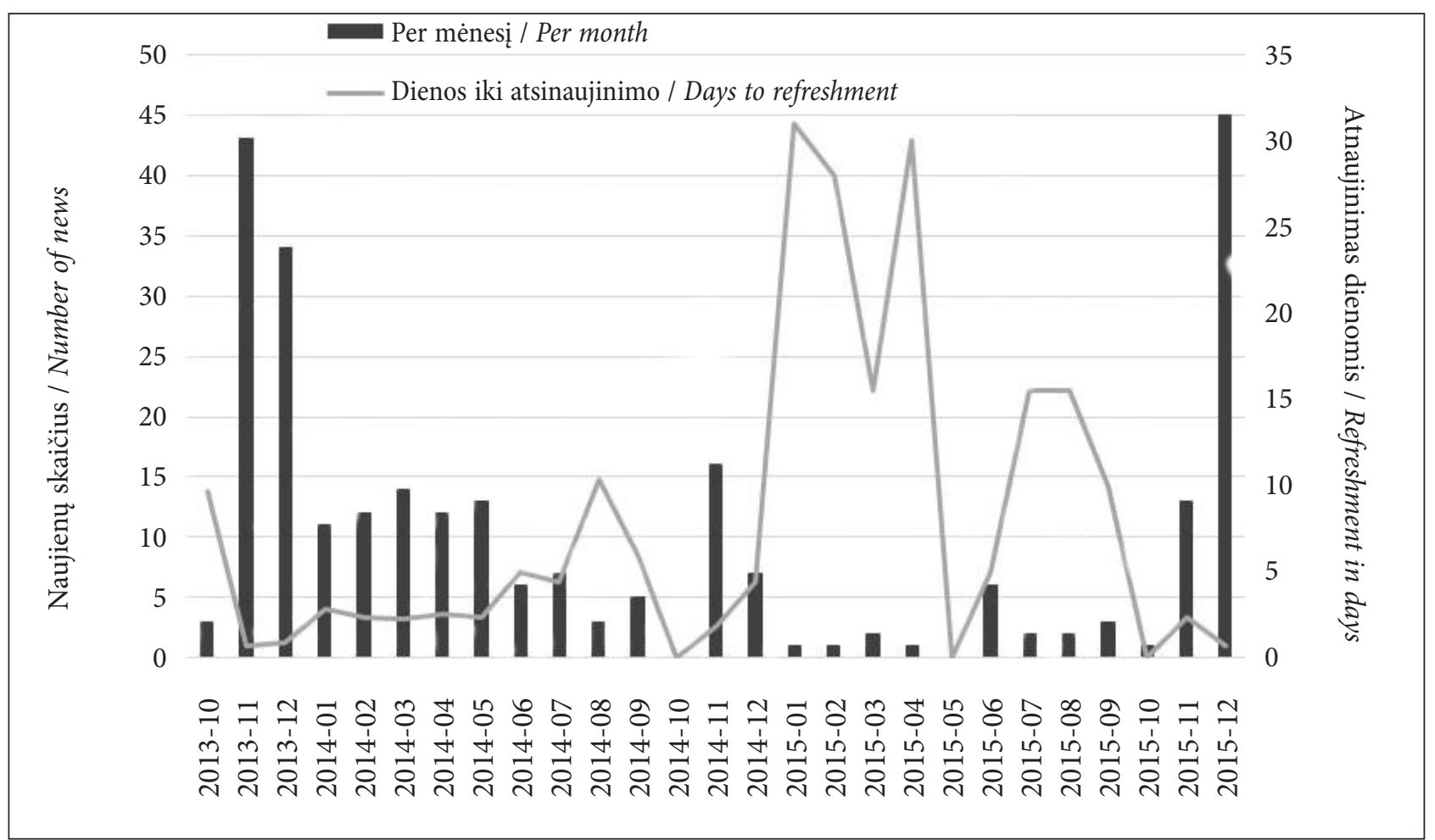

7 pav. Naujienų skaičius per mènesị ir jų atnaujinimas dienomis lietuviškoje Facebook paskyroje „Klimato kaita“ Fig. 7. The number of news in different months and refreshment of the news on Facebook link 'Klimato kaita (Climate change)'

\section{DISKUSIJA IR APIBENDRINIMAS}

\section{Klimato kaitos informacinis laukas}

Apibendrinus interneto paieškos sistemų Google, Bing ir Yahoo populiariausiųjų dešimtukų rezultatus, galima išskirti savitus informacijos apie klimato kaitą modelius. Neabejotina, kad Google yra svarbiausia žinių apie KK platforma, užimanti daugiau kaip 96 \% visų paieškų lauko. Google apibūdinamas kaip patikimas (daugiausia remiamasi oficialiais ir valstybiniais informacijos (AM, LHMT, EEA, ES komisija) šaltiniais), tačiau mažai dinamiškas (informacija stokoja aktualumo (naujesnè kaip $2014 \mathrm{~m}$. informacija sudaro tik kiek daugiau kaip $50 \%$ ) ir vizualumo), sistemos modelis. Paieškos rezultatų struktūra Bing artima britiškam dinamiškam modeliui, kuris būdingas Jungtinei Karalystei, Vokietijai (Kažys, 2016); čia svarbus vaidmuo tenka internetinei žiniasklaidai (mūsų atveju - delfi.lt; lrytas.lt) ir nuolat papildomiems informacijos šaltiniams (Facebook, 7broliaimiegantys). Paieškos sistemos Yahoo rezultatai orientuoti ì jaunąją kartą. Informaciją stengiamasi pateikti ne vien dinamiškai, bet ir vizualiai (youtube.com; Facebook vaizdai, videomedžiaga).
Yahoo pasitaiko su KK nesusijusios informacijos, kuri sudaro net $17 \%$ bendro kiekio. Tikètina, kad minèti interneto informacijos struktūros modeliai yra mažai kintantys. Viena iš priežasčių, kad „Apskritai Lietuvoje beveik nèra savarankiško diskurso klimato kaitos tematika - lietuviškasis diskursas klimato kaitos tematika yra pastūmètas pasaulinio, vakarų šalyse vykstančio diskurso, skatinamas pasaulinių i̇vykių..." (Balžekienè ir kt., 2008), o per 2008-2011 m. diskurso pokytis žiniasklaidoje buvo neryškus (Jančevskaitė, Telešienè, 2013).

Klimato kaitos informacinio lauko kiekybiniai rodikliai yra jautrūs kontekstui, t. y. skirtingą informaciją gausime, jeigu „klimato kaitą“ traktuosime tik kaip frazę ar kaip komunikacinę „žinutę“. Paieškoje Google suvedus bendrą kontekstą turinčias frazes "klimato kaita“ ir „visuotinis atšilimas" (žiūrèta 201703 29) rezultatų, atitinkančių užklausas, skaičius yra atitinkamai 187 ir 251 tūkst. Tik Europos Komisijos klimato politikos puslapis (ec.europa.eu/clima/change/causes_) pateko ì abiejų frazių populiariausiųjų dešimtuką. Kitas svarbus aspektas, kad tas pats terminas skirtingomis kalbomis gali turèti skirtingą krūvị 
(Kažys, 2016). Jeigu anglų kalba terminas climate change (klimato kaita) dažnai vartojamas kaip global warming (visuotinis atšilimas) sinonimas, tai vokiečiu kalbos terminai Klimawandel (klimato kaita) ir globale Erwärmung (visuotinis atšilimas) nèra tapatūs. Nebejotina, kad internete ieškant ne frazès „klimato kaita“, bet klimato kaitos konteksto, informacijos kiekis išauga kiekybiškai, tačiau ar išplètus paieškos ribas išauga informacijos kokybè - klausimas tebèra atviras. Siekiant išryškinti kokybinius klimato kaitos aspektus reikalingi nuodugnesni termino kaip komunikacinès „žinutès“ tyrimai.

\section{Naujausios informacijos svarba}

Jungiamoji visų interneto paieškos sistemų rezultatu grandis yra Vikipedija. Straipsnis apie KK lietuviškoje Vikipedijoje išlieka aukščiausiai reitinguojamas interneto paieškos sistemose (3 lentelè) ir gausiai lankomas (4 pav.), tačiau jame pateikiama informacija kokybès ir naujumo prasme nepajègi tenkinti šiuolaikinès visuomenès poreikių. Straipsnio apimtis ir peržiūrų skaičius atsilieka nuo daugelio Baltijos jūros regiono valstybių. Nuo $2013 \mathrm{~m}$. palaipsniui mažejantis puslapi aplankančių asmenų skaičius rodo, kad pateikiamos informacijos kokybė nèra gera. KK procesų pažinimas, vertinant Vikipedijos straipsnio kontekstą, atsilieka nuo pasaulinių tendencijų daugiau kaip penkeriais metais, o tokioje dinamiškoje terpeje kaip internetas tai labai ilgas laikotarpis. Mažejjantis susidomejjimas klimato kaitos klausimais kertasi su Eurobarometro (2014a) apklausų duomenimis apie augančią KK svarbą tarp Lietuvos gyventojų bei su Lietuvos Respublikos KK paskelbimu nacionaliniu prioritetu (Aplinkos ministerija, 2013). Tyrimo rezultatai implikuoja prielaidą, kad KK yra tik deklaratyviai skelbiamas nacionalinis prioritetas. Plačiau KK nacionalinio prioriteto klausimas aptartas J. Kažio ir kt. (2016) tyrime. Aukščiausiai interneto paieškos sistemose reitinguojamuose ir lankomuose puslapiuose informacija nèra pakankamai atnaujinama (1a pav.), išsami (1b pav.), tik konstatuojanti faktus (1d pav.) bei stokojanti originalumo (1e pav.). Panašūs interneto paieškos rezultatų bruožai būdingi visoms buvusioms Rytų bloko Baltijos jūros regiono šalims (Kažys, 2016). Siekiant pagerinti Vikipedijos puslapio turinị reikètų ne tik išplèsti ir papildyti esamą informaci- ją naujais duomenimis, bet ir ieškoti būdų, kaip padidinti plačiosios visuomenès sąmoningumo lygi.

$8 \%$ - tiek naujienų vidutiniškai tenka informacijai apie klimato kaitą AM, AAA, LHMT ir AK interneto puslapiuose Lietuvoje. Daug tai ar mažai? Kadangi ị aplinkos sąvoką telpa vanduo, oras, dirvožemis, gyvoji gamta bei jų stebèsena, taip pat cheminių medžiagų ir atliekų tarša ir kontrolè, o dar prie Aplinkos ministerijos funkcijų "prikabinta“ daugiabučių renovacijos programa - tai nèra mažai. Tačiau kova su klimato kaita yra paskelbta nacionaliniu prioritetu, o ši sąvoka jungia visos aplinkos pokyčius globaliu ir lokaliu lygiu - tai lašas jūroje. Iš dalies naujos informacijos apie KK trūkumą užpildo internetinė žiniasklaida (Jančevskaitè, Telešienè, 2013), tačiau žurnalistai vis dar menkai rašo su klimato kaita siejamomis temomis (Pilibaitytè, 2016). Žiniasklaida patenka ił populiariausiųjų dešimtuką tik paieškos sistemoje Bing. Tyrimas atskleidè, kad lietuviškiems puslapiams būdingi panašūs KK informacijos internete bruožai kaip Estijai, Latvijai ir Lenkijai. Kokybine prasme informacija labai skiriasi nuo pateikiamos daniškuose, norvegiškuose, suomiškuose ir švediškuose puslapiuose (Kažys, 2016). Labai tikètina priežastis - kultūriniai, socialiniai ir ekonominiai šalių skirtumai. A. Balžekienè ir kt. (2008) teigia, kad „Lietuvoje globalias rizikas užgožia vietos problemos, o klimato kaitos klausimai, ypač žiniasklaidoje, neretai paliekami paraštėse“. J. Kažys (2016), tirdamas Baltijos jūros regiono valstybes, nustatè, kad klimato kaitos informacijos kiekis internete vietinèmis kalbomis priklauso ne tik nuo šalies gyventojų skaičiaus, bet ir nuo interneto prieinamumo laipsnio bei aukštesnio anglų kalbos mokejjimo lygio. Tikètina, kad ateities technologinis progresas ir nauji mokslo pasiekimai bei išaugsiantis anglų kalbos žinių lygis leidžia tikètis aukštesnès KK informacijos kokybès Lietuvoje.

\section{Europinių institucijų ir NVO vaidmuo}

Neabejotina, kad EEA interneto puslapis yra naujausios ir išsamiausios informacijos apie klimato kaitą šaltinis. Šalia populiariausių paieškos sistemų dešimtukuose figūruoja kitas ES Komisijos administruojamas puslapis apie KK. Paradoksalu, kad Lietuvos gyventojai daugiau informacijos apie klimato kaitą gauna iš regioninių 
Europos Sąungos puslapių nei iš vietinių. Lietuva yra vienintelè Baltijos jūros regiono valstybé, kuri prioritetą teikia išoriniams šaltiniams (Kažys, 2016). EEA ir ES puslapiai kartu su plètiniais užèmė $50 \%$ populiariausiųjų dešimtuko rezultatų (2016 0920 duomenys). Viena iš populiarumo priežasčių, tikètina, puslapių daugiakalbiškumas, visa informacija skelbiama visomis ES kalbomis. Kita priežastis - nuolatinis žmogiškųjų ir finansinių ištekliu palaikymas, kadangi informavimo apie KK svarba pabrèžiama ES dokumentuose (Europos Komisija, 2013). Pagrindinis EEA ir ES puslapių trūkumas yra tai, kad informacija yra labiau orientuota i visą ES regioną ir mažai dèmesio skiriama lokaliems klausimas (pvz., Lietuvos kontekstas). Taip pat šiuose puslapiuose daugiau informacijos pateikiama tik anglu kalba. Lietuviškų institucijų, tiesiogiai siejamų su klimato kaita (AM, AAA ir LHMT), puslapiuose informacija yra išskaidyta ir nepakankamai išsami bei nauja. Pavyzdžiui, LHMT puslapis yra vienas iš informacijos apie KK lyderių interneto paieškos sistemose (1 vieta Google, 20160920 duomenys), tačiau išsamesnè analizè parodè, kad populiarumas didele dalimi nulemtas vartotojui atsitiktinai spustelejus nuorodą beieškant informacijos apie orų prognozes. LHMT puslapyje klimato kaitos rubrikos peržiūrai tenka itin menka dalis, palyginti su oru prognozèmis. Galimas sprendimas siekiant padidinti valstybinių lietuviškų puslapių aktualumą yra labiau išnaudoti jau esančios AIVIKS (Aplinkos informacijos valdymo integruota kompiuterinè sistema) potencialą tobulinant esamą klimato kaitos paskyrą, kurioje būtų patalpinta išsami ir nuolat atnaujinama informacija. Kitas variantas yra specializuoto oficialaus valstybinio puslapio, skirto KK, atsiradimas (tokie puslapiai egzistuoja Danijoje, Suomijoje, Švedijoje, Vokietijoje), tačiau tam reikalingi nemenki žmogiškieji, moksliniai, technologiniai ir finansiniai ištekliai.

Šviesa tunelio gale galime laikyti nuo $2013 \mathrm{~m}$. aktyvų aplinkosauginių NVO įsijungimą sprendžiant KK klausimus (dalyvavimas COP19 ir COP21 renginiuose, paskyros Facebook atsiradimas ir kt.). NVO veiklą galima priskirti kylančiam „klimato teisingumo“ požiūriui. Tačiau daug kas priklausys nuo to, kaip sèkmingai judejjimas sukurs viešąsias erdves ar tinklus, kuriuose mokslininkai, inžinieriai, piliečiai galès bendradarbiauti, keistis žiniomis (Jamison, Rinkevičius, 2010).
Aplinkosaugos koalicijos ir kitų NVO vaidmuo buvo labai svarbus aktyviai kuriant ir vykdant KK politiką Lietuvoje (Kažys ir kt., 2016). Neabejotina, kad formuojant KK politiką (Jonušauskaitè, 2014) ir politikos advokaciją (Ringailaitè, 2014) NVO pasieké svarių laimejjimų. Interneto svetainių tyrimo rezultatai patvirtino, kad NVO veikla labiau nukreipta i KK politiką, nei orientuota $i$ jungiančią informacinę-edukacinę grandi tarp valstybinių institucijų ir piliečių. Aplinkosauginiai NVO puslapiai sudaro tik dešimtadalị su KK susijusios informacijos, daugiau kaip per pusantrų metų tyrimą ši padètis mažai tepasikeitè. I populiariausiųjų paieškos sistemos Google rezultatų dešimtuką patenka tik Baltijos aplinkos forumo (BEF) puslapis, AK puslapis pakilo iki 12 pozicijos (2016 0920 duomenys), o paskyra Facebook rikiuojasi šeštajame šimtuke. Taip pat reikia pripažinti, kad pateikiama informacija nèra nauja bei sietina su konkrečiais NVO projektais ir veiklos viešinimu. Pasakymas, kad nèra finansavimo (projektų) - nèra naujienų (intereso) - itin gajus. Galimas sprendimas siekiant padidinti NVO lietuviškų puslapių aktualumą ir nuolatinị informacijos naujinimą yra nepertraukiamas su KK susijusios veiklos finansavimas, didesnè pačių aplinkosauginių NVO orientacija ne tik $\mathfrak{i}$ valstybinį sektorių, bet ir plačiąją visuomenę. Kalbant apie interneto informacijos KK klausimais kokybę, praverstų ittakingas tarptautinès aplinkosauginès NVO (Greenpeace, World Wide Fund) puslapis lietuviu kalba; tokie interneto puslapiai vaidina svarbų vaidmenị Rusijoje, Ukrainoje, Vokietijoje (Kažys, 2016).

Gauta 20170306 Priimta 20170407

\section{Literatūra}

1. Anderson A. 2009. Media, politics and climate change: towards a new research agenda. Sociology Compass. 3(2): 166-182.

2. Balžekienė A., Butkevičienè E., Rinkevičius L. 2009. Ekologinių ir technologinių rizikų suvokimas: Lietuvos visuomenès požiūriai ir nuostatos. Filosofija. Sociologija. 20(4): 237-249.

3. Balžekienè A., Telešienè A., Rinkevičius L. 2008. Klimato kaita: socialinio rizikos suvokimo ir žiniasklaidos diskurso Lietuvoje 
konfigūracijos. Sociologija. Mintis ir veiksmas. 22(2): 5-19.

4. Bray D. 2010. A survey of the perspectives of climate scientists concerning climate change and climate science in the Baltic Sea basin. SurBACC 2010, International BALTEX Secretariat, Publication No. 48.

5. CCCAG. 2010. Communicating climate change to mass public audiences, The Climate Change Communication Advisory Group. 14 p.

6. Center for Research on Environmental Decisions. 2009. The Psychology of Climate Change Communication: A Guide for Scientists, Journalists, Educators, Political Aides, and the Interested Public. New York. 48 p.

7. Chitika. 2013. Chitika Insights - The Value of Google Result Positioning, report, June 7, 2013. http://info.chitika.com/uploads/4/9/2/1/ 49215843/chitikainsights-valueofgoogleresultspositioning.pdf.

8. Dél Nacionalinès klimato kaitos valdymo politikos strategijos 2013-2020 m. tikslu ir uždaviniu igyvendinimo tarpinstitucinio veiklos plano patvirtinimo. 2013. LR Vyriausybè. Nutarimas Nr. 366, 20130423.

9. ES prisitaikymo prie klimato kaitos strategija. $\operatorname{COM}(2013) 216$ final, Briuselis, 20130416.

10. Eurobarometer. 2012. Europeans and Their Languages. Special Eurobarometer, no. 386, The European Commission. http://ec.europa. eu/public_opinion/archives/ebs/ebs_386_ en.pdf.

11. Eurobarometer. 2014a. Climate change. Special Eurobarometer no. 409, The European Commission. http://ec.europa.eu/public_ opinion/archives/ebs/ebs_409_en.pdf.

12. Eurobarometer. 2014b. Public perceptions of science, research and innovation. Special Eurobarometer 419, TNS Opinion \& Social.

13. Green European: Environmental Behaviour and Attitudes in Europe in a Historical and Cross-Cultural Comparative Perspective. 2017. A. Telešienè, M. Gross (eds.), Routledge/ European Sociological Association studies in European societies 22, Routledge, Taylor \& Francis Group, London-New York. $253 \mathrm{p}$.

14. Greer J. D., Mensing D. 2006. The evolution of online newspapers: A longitudinal content analysis, 1997-2003. Internet
Newspapers - the Making of a Mainstream Medium, ed. X. Li. Mahwah. New Jersey: Routledge. p. 13-32.

15. Informacinés visuomenès plètros 2015 mety apžvalga. 2016. Informacinès visuomenès plètros komitetas prie Susisiekimo ministerijos. http://statistika.ivpk.lt/ataskaitos/atsisiusti/6051

16. IPCC. 2014. Climate Change 2014: Impacts, Adaptation, and Vulnerability. Contribution of Working Group II to the Fifth Assessment Report of the Intergovernmental Panel on Climate Change [Field, C. B., V. R. Barros, D. J. Dokken, K. J. Mach, M. D. Mastrandrea, T.E. Bilir, M. Chatterjee, K. L. Ebi, Y. O. Estrada, R. C. Genova, B. Girma, E. S. Kissel, A. N. Levy, S. MacCracken, P. R. Mastrandrea, and L. L. White (eds.)]. Cambridge University Press, Cambridge, United Kingdom and New York, NY, USA. 1132 p.

17. Jamison A., Rinkevičius L. 2010. Socialinių judejimų vaidmuo formuojant viešajį klimato kaitos diskursą ir žinojimą. Sociologija. Mintis ir veiksmas. 27(2): 166-185.

18. Jančevskaitė R., Telešienè A. 2013. Klimato kaitos diskursas Lietuvos spausdintineje ir internetinèje žiniasklaidoje. Filosofija. Sociologija. 24(2): 92-99.

19. Jonušauskaitè G. 2014. Projekto „Aplinkosaugos NVO vaidmens stiprinimas formuojant klimato kaitos politika" igyvendinimo patirtis: pasiekimai ir iššūkiai. Pranešimas seminare „NVO vaidmens stiprinimas klimato kaitos srityje: išmoktos pamokos ir ateities perspektyvos", $2014 \mathrm{~m}$. birželio $18 \mathrm{~d}$. http://aplinkosauga. lt/wp-content/uploads/2014/07/Projektoapzvalga.pdf

20. Juraitė K., Telešienè A. 2009. Ekologinès rizikos diskursas žiniasklaidoje: tyrimo teorinès bei metodologinès prielaidos. Filosofija. Sociologija. 20(4): 227-236.

21. Kažys J., Leal Filho W., Stonevičius E., Valiuškevičius G., Rimkus E. 2013. Climate change impact on small coastal river basins: from problem identification to adaptation (the Klaipeda City case study). Climate and Development. 5(2): 113-122.

22. Kažys J. 2016. The internet search results on the term 'climate change' by local Baltic Sea Region languages. Proceedings of Fifth 
International Conference on Climate Change Adaptation 2016 Challenges and Issues in Adaptation. Toronto, Canada, International Center for Research \& Development. 23-30. http://uniqueca.com/archieves/proceedings/ CCA2016.pdf.

23. Kažys J., Rimkus E., Naujèkaitė J. 2016. From case studies to policy-making: adapting to climate change in Lithuania. Climate Adaptation Governance in Cities and Regions: Theoretical Fundamentals and Practical Evidence, ed. J. Knieling, John Wiley \& Sons, Ltd, Chichester, UK. doi: 10.1002/9781118451694.ch12.

24. Leviston Z., Price J., Bishop B. 2014. Imagining climate change: The role of implicit associations and affective psychological distancing in climate change responses. European Journal of Social Psychology. 44: 441-454.

25. Lietuvos Respublikos 6-asis Nacionalinio JTBKKK igyvendinimo pranešimas ir 1-oji dvimetè ataskaita. 2013. Vilnius: Lietuvos Respublikos aplinkos ministerija. $150 \mathrm{p}$.

26. Nacionaline klimato kaitos valdymo politikos strategija. 2012. LR Seimas. Nutarimas Nr. XI2375, 20121106.

27. Moser S. C., Dilling L. 2012. Communicating Climate Change: Closing the Science-Action Gap. The Oxford Handbook of Climate Change and Society, eds. J. S. Dryzek, R. B. Norgaard, and D. Schlosberg. p. 162-174, doi: 10.1093/ oxfordhb/9780199566600.003.0011.

28. Pilibaitytė V. 2016. Bijai klimato kaitos? Neik i žurnalistiką. Klimato (r)evoliucija, red. G. Gimžauskas. Europos Komisijos atstovybè Lietuvoje. 7-14.

29. Piwowarczyk J., Hansson A., Hjerpe M., Chubarenko B., Karmanov K. 2012. Climate change in the Baltic sea region: a cross-country analysis of institutional stakeholder perceptions. Ambio. 41(6): 645-655.

30. Ringailaitè I. 2014. Klimato kaitos politikos advokacijos gaires Lietuvos NVO. Pranešimas seminare „NVO vaidmens stiprinimas klimato kaitos srityje: išmoktos pamokos ir ateities perspektyvos", $2014 \mathrm{~m}$. birželio $18 \mathrm{~d}$. http:// aplinkosauga.lt/wp-content/uploads/2014/07/ Advokacijos-gaires-NVO.pdf

31. Rinkevičius L. 2009. Rizikos suvokimas, viešoji komunikacija ir inovatyvus valdymas žiniu visuomeneje. RINOVA, LVMS projektas, sutartis Nr. C-10/2007, C-10/2008, C-10/2009.

32. StatCounter. 2016. Search_engine-LT-quarterly-2015. StatCounter Global Stats. http:// gs.statcounter.com/\#search_engine-LT-quarterly-201504-201603

33. Stockholm Environment Institute. 2012. The BalticClimate toolkit: Bringing data and resources to key actors in the public and private sectors. SEI factsheet. https://www.seiinternational.org/mediamanager/documents/ Publications/SEI-Factsheet-TheBalticClimate Toolkit.pdf.

34. Telešienè A. 2009. Klimato kaitos diskursas Lietuvoje: reikšmių konstravimas dienraščiuose. Filosofija. Sociologija. 20(4): 250-258.

35. Valiuškevičius G. 2015. VU hidrometeorologijos specialybės studentų baigiamųjų darbų analizé klimato kaitos diskurso kontekste. Geologija. Geografija. 1(1): 36-44.

36. van der Linden S. L., Leiserowitz A. A., Feinberg G. D., Maibach E. W. 2014. How to communicate the scientific consensus on climate change: plain facts, pie charts or metaphors? Climatic Change. 126(1-2): 255-262.

37. Vidickienè D., Melnikienè R., GedminaitèRaudonė Ž. 2010. Galimybès ir grèsmès, kylančios Lietuvos žemès ir mišku ūkiui dèl klimato kaitos. Management theory and studies for rural business and infrastructure development. 22(3): 9.

38. Wiréhn L. 2011. Questionnaire Results Regional Conditions, Problems and Potentials due to Climate Change. BalticClimate final report, Centre for Climate Science and Policy Research.

39. 2020-2030 m. klimato ir energetikos politikos strategija. COM(2014) 15 final, Briuselis, 20140122 


\section{Justas Kažys}

\section{DIMENSION OF CLIMATE CHANGE ON LITHUANIAN INTERNET: WHAT BASIC STATISTIC INFORMATION COULD TELL}

\section{Su m mary}

Climate change (CC) is one of the major topics discussed all over the world. Moreover, the internet is the main source of information on this topic. The main goal of this research is to assess the quantity and the quality of information about climate change presented on internet using data of internet search engines and environmentrelated organizations' websites. The obtained results could be used for filling the gaps of information and for planning information optimization possibilities in future for governmental institutions.

Statistical information of the phrase 'climate change' on different internet search engines was used for the research. The top10 results of request 'climate change' (using Google, Bing and Yahoo internet search engines) were analysed in six different periods from 4 February 2015 to 20 September 2016 (Table 1). Further, quantitative and qualitative assessment of the top 10 positions of search results was based on six questions: who, where, when, why, how, and how much (Table 2). Wikipedia topic 'climate change' (in Lithuanian) was analysed in greater detail. The Lithuanian internet pages of the Ministry of Environment (AM), Environmental Protection Agency (AAA), Lithuanian Hydrometeorological Service (LHMT), Environmental NGOs Coalition (AK), and European Environmental Agency (EEA) were highlighted for analysis of basic information and news flow about climate change. Moreover, news flow on the $\mathrm{Fa}$ cebook page 'Klimato kaita (climate change)' from September 2013 to December 2015 was analysed.

Only more than half of Google top 10 search results were new (Fig. 1a), while Bing and Yahoo more often contained refreshed information about CC because of presents of internet news portals (delfi.lt, 7broliaimiegantys.wordpress.com, facebook.com/klimatokaita). Most of the top10 search results delivered wide range information (at least with links) about CC (Fig. 1b). 48\% of Google top10 search results (Fig. 1c) were occupied by governmental websites (AM, AAA, LHMT, ES, EEA), while for Yahoo search the dominating category was 'other' (videos, images), and for Bing 'social nets' (7broliaimiegantys, facebook). The number of websites providing only information about CC were almost equal to the number of websites which had educational purposes (Fig. 1d). The adaptive type of material was prevailing on top10 search results (Fig. 1e); however, the tendency of growing originality was significant. The top 10 search results on Bing and Yahoo were orientated to global information coverage, while a large segmentation of geographical coverage scales on Google search results were noticeable (Fig. 1f).

The social network (Wikipedia, Facebook, YouTube) occupied more than $50 \%$ of top 3 positions of search (Fig. 2). Comprehensive analysis of statistical information revealed that the most visited and observable source of internet-based information was Wikipedia (Table 3); also, popular links were Google images and EEA website. Only Wikipedia internet website was providing information with phrase 'climate change' in every Baltic Sea Region language (Fig. 3), but the amount and views of information differed a lot. The fluctuation of the number of views in Wikipedia depended on political activity - it was increasing before the UN Climate Change Conference COP15 meeting in Copenhagen and the presidency of Lithuania of EU Council in 2013 and refreshment of information and decreasing from 2012 when the webpage was not supplemented with new facts (Fig. 4a). Also, intra-annual changes very much depended on people holidays time (Fig. 4b).

Moreover, the research showed the existing gaps in information and possible ways for improvement by providing better quality and novelty through internet sources. The refreshment of information about CC on the main webpages (AAA, AK, AM, EEA and LHMT) was not constant (Table 4). The main topic was CC politics and mitigation; adaptation to $\mathrm{CC}$ was presented only in EEA webpage. $44-74 \%$ of CC news were published during the last four years (2012-2015) (Fig. 5). Yearly dynamics of the number of news strongly depended on political situation: stagnation during economic crisis and different priorities of the Ministry of Environment (including building renovation, dumping grounds, fishery, etc.) and rapid increase before Lithuanian presidency of EU Council. Seasonal fluctuation of news (Fig. 6a) had the same tendencies as Wikipedia views (Fig. 4b). AM, AAA and LHMT together produced 12.4 news per year, i.e. only one news per month (Fig. 6b). The news feed on Facebook CC platform supported by AK (coalition of environmental NGOs) was not stable as well (Fig. 7): the main activities in November-December 2013 and 2015 were related to AK participation in the UN Climate Change Conference COP19 and COP21 events.

Keywords: climate change, environment protection, internet search engines, European Environmental Agency, mass media, NGOs 